NBER WORKING PAPER SERIES

\title{
INCOME INEQUALITY, SOCIAL MOBILITY, AND THE DECISION TO DROP OUT OF HIGH SCHOOL
}

\author{
Melissa S. Kearney \\ Phillip B. Levine \\ Working Paper 20195 \\ http://www.nber.org/papers/w20195
NATIONAL BUREAU OF ECONOMIC RESEARCH
1050 Massachusetts Avenue
Cambridge, MA 02138
June 2014

\begin{abstract}
We are indebted to our BPEA discussants Robert Moffitt and Miles Corak and to Editor Janice Eberly for detailed comments that have greatly improved the paper. We also thank Miles Corak, Sue Dynarski, Nora Gordon, Caroline Hoxby, Judy Hellerstein, Robin McKnight, and Lesley Turner for helpful conversations and comments on an earlier draft. We acknowledge helpful comments from seminar participants at American University School of Public Policy, Notre Dame University, Stanford University, University of New Hampshire, University of Texas at Austin, the Federal Research Bank of Cleveland Workshop on Income Distribution, and the NBER Universities Research Conference on Poverty, Inequality, and Social Policy. We thank Riley Wilson for research assistance. We are grateful to the Smith Richardson Foundation for providing financial support for this project. Any views expressed are those of the authors alone. The views expressed herein are those of the authors and do not necessarily reflect the views of the National Bureau of Economic Research.
\end{abstract}

NBER working papers are circulated for discussion and comment purposes. They have not been peer-reviewed or been subject to the review by the NBER Board of Directors that accompanies official NBER publications.

(C) 2014 by Melissa S. Kearney and Phillip B. Levine. All rights reserved. Short sections of text, not to exceed two paragraphs, may be quoted without explicit permission provided that full credit, including $\odot$ notice, is given to the source. 
Income Inequality, Social Mobility, and the Decision to Drop Out of High School

Melissa S. Kearney and Phillip B. Levine

NBER Working Paper No. 20195

June 2014, Revised March 2016

JEL No. D31,I24,J24

\begin{abstract}
$\underline{\text { ABSTRACT }}$
It is widely documented that places with higher levels of income inequality have lower rates of social mobility. But it is an open question as to whether this reflects a causal relationship. We propose that one channel by which higher rates of income inequality might lead to lower rates of upward mobility is through lower rates of human capital investment among low-income individuals. Specifically, we posit that greater levels of income inequality could lead low-income youth to perceive a lower return to investment in their own human capital. Such an effect would offset any potential "aspirational" effect coming from higher educational wage premiums. The data are consistent with this prediction: low-income youth are more likely to drop out of school if they live in a place with a greater gap between the bottom and middle of the income distribution. This finding is robust to a number of specification checks and tests for confounding factors. This analysis offers an explanation for how income inequality might lead to a perpetuation of economic disadvantage and has implications for the types of interventions and programs that would effectively promote upward mobility among low-SES youth.
\end{abstract}

\author{
Melissa S. Kearney \\ Department of Economics \\ University of Maryland \\ 3105 Tydings Hall \\ College Park, MD 20742 \\ and NBER \\ kearney@econ.umd.edu \\ Phillip B. Levine \\ Department of Economics \\ Wellesley College \\ 106 Central Street \\ Wellesley, MA 02481 \\ and NBER \\ plevine@wellesley.edu
}




\section{INTRODUCTION}

International comparisons show that the United States is a country that ranks high in its level of income inequality and low in its level of social mobility. Corak (2006) - building on the theoretical contributions made by Solon (2004) - was the first to show empirically that this relationship is part of a broader pattern that exists across countries. Countries with high levels of inequality also tend to exhibit lower rates of social mobility, as measured by greater intergenerational income persistence. In a speech on January 12, 2012, Council of Economic Advisors Chairman Alan Krueger popularized this relationship as “The Great Gatsby Curve.” Using data on U.S. states, we construct a Gatsby Curve for the United States: Figure 1 shows that states with greater levels of income inequality tend to have lower rates of social mobility. ${ }^{1}$ This positive cross-sectional relationship between rates of income inequality and intergenerational income persistence often leads to claims about causality, implying that higher rates of income inequality lead to lower rates of mobility. ${ }^{2}$ But, it is very much an open question as to whether income inequality actually causes lower rates of social mobility, and if so, through what channels.

\footnotetext{
${ }^{1}$ Social mobility is a concept that includes the likelihood of moving up or down in the income distribution, which is specifically labeled as economic mobility, but also may include changes in position in other distributions as well, like educational attainment, occupational status, and health. We restrict our attention to economic mobility in this paper, but adopt the common approach of using the terms social and economic mobility interchangeably. The specific mobility measure used here is taken from Chetty, et al. (2014a), and reflects the correlation in the income rank of parents and their adult child. It is worth noting that if we replaced the Gini coefficient with alternative measures of income inequality, we see the same relationship. In particular, the figure looks the same using the 50/10 ratio of income, which is our primary measure of income inequality in this paper, as described below.

${ }^{2}$ For example, Jason Furman, current Chair of the Council of Economic Advisers, stated "I think we think all else being equal, more inequality will lead to less relative mobility," (in The Atlantic's Economy Summit 2014 (available http://fora.tv/2014/03/18/conversation_with_jason_furman - 7:37 into the interview). Sawhill (2014) asserts that when the rungs of the ladder are farther apart, it gets harder to climb them.
} 
As an empirical matter, researchers have been unable to determine whether high income inequality leads to lower rates of economic mobility. For example, the important, data-intensive work of Chetty, Hendren, Kline, and Saez (2014a) documents that places with higher rates of social mobility tend to be characterized by lower levels of income inequality, along with differences in other characteristics like less residential segregation and lower rates of singleparenthood households. Despite the significant value of that research, it does not attempt to estimate causal pathways either from income inequality to social mobility, or vice versa, nor from inequality to other outcomes.

In this paper we propose and investigate one important channel through which higher rates of income inequality might lead to lower rates of upward economic mobility of individuals from low socioeconomic status (SES) backgrounds: curtailed investment in human capital. We hypothesize that income inequality can negatively affect the perceived returns to investment in education from the perspective of an economically disadvantaged adolescent - either through an effect on actual returns and/or through an additional effect on the perception of those returns. The notion we have in mind is that a greater gap between the bottom and the middle of the income distribution might lead to a heightened sense of economic marginalization such that an adolescent at the bottom of the income distribution does not see much value in investing in his/her human capital. We call this "economic despair." This could be due to adverse neighborhood or school conditions driven by elevated rates of income inequality, but it need not be. This mechanism offers an explanation within the standard human capital framework of decision-making for why greater inequality - which might reflect in part a greater return to human capital investment - does not necessarily lead to greater rates of educational attainment for certain segments of the population. 
To empirically explore this idea, we investigate whether places characterized by higher rates of income inequality lead to lower rates of high school graduation among individuals from low-SES families, controlling for individual and family demographics and broader contextual factors. Greater educational attainment is a key pathway by which an individual from a lowincome background can move up in the income distribution and obtain a middle class life, or potentially even higher. If children from low-income backgrounds are responding to large gaps between their economic reality and middle-class life by dropping out of school, that would perpetuate economic disadvantage and impeded rates of upward mobility. It would be a mechanism through which income inequality and social mobility were causally linked and might explain why certain places regularly seem to have high inequality and low mobility, or vice versa. Furthermore, it would have profound implications for society and the types of interventions needed to break the cycle.

Our discussion in Section II of relevant background facts and ideas addresses a number of important issues. We describe some key reasons why the Gatsby Curve might not reflect a causal negative relationship between income inequality and rates of social mobility. First, there is the well-known empirical complication that the level of income inequality in a place is correlated with many other factors that also might impact rates of social mobility. Empirically identifying which factor is driving what is extremely difficult. Furthermore, some have argued that the relationship might be merely descriptive, and not actually consequential.

In Section II we also describe an empirical puzzle that others have pointed out, namely that income inequality has been rising for many decades with no observable decrease in social mobility rates. We describe two features of our model and empirical results that might help resolve this puzzle. First, we argue that adolescents' perceptions and expectations about the 
society around them and their place in it are likely shaped by the more permanent features of the environment they grow up in, including long-term measures of inequality. Transitory or very recent changes in inequality are less likely to have a profound effect on adolescents’ perceptions and experiences. It might be the case that the effects of rising income inequality are not yet manifested in observed rates of social mobility. Second, we propose that lower-tail income inequality (as captured by the ratio of household income at the $50^{\text {th }}$ and $10^{\text {th }}$ percentiles of the distribution - the "50/10 ratio") is more relevant to thinking about upward mobility, than is inequality at the top of the distribution. Lower-tail income inequality has been fairly flat over recent decades.

In Section III we present a stylized model of the decision to drop out of high school. This simple model generates the possible existence of both the aspirational and “despair” effects of greater levels of income inequality within an otherwise standard human capital investment framework. In this section we also review related conceptual models.

We then turn to a detailed description of our empirical analysis and results in Sections IV and V. We use individual-level data pooled from five national surveys to investigate how income inequality affects the rate at which low socioeconomic status (SES) youth drop out of high school, controlling for individual background characteristics and aggregate-level contextual factors. The data provide robust evidence that higher levels of lower-tail income inequality lead boys from low-SES households to drop out of high school with greater frequency, controlling for a rich set of individual- and state-level characteristics. That data separately identify a negative effect of a higher high school wage premium on high school dropout rates and a positive effect of lower-tail income inequality on high school dropout rates. These two offsetting effects are 
consistent with our modified human capital investment model, in which inequality has competing aspirational and despair effects.

We also report the results from a number of alternative specifications. First, we investigate whether the observed relationship between income inequality and drop-out rates is being driven by a number of potential confounding factors, such as other features of the income distribution (including upper-tail income inequality), aggregate poverty rates, or incarceration rates, among others. Second, we devote considerable attention to the potential mechanisms that drive the observed empirical relationship between lower-tail income inequality and the decision of low-SES youth to drop out of school. The data do not offer support for a number of potential explanations for the link, including most notably, residential segregation or eroded public school funding. Although we are ultimately unable to empirically establish a precise mechanism, the empirical relationship we document is consequential, implying that greater levels of income inequality can perpetuate lower rates of social mobility in part by leading low-income youth to engage in more drop-out behavior. We conclude with a discussion of policy implications.

\section{BACKGROUND}

The cross-sectional correlation between income inequality and intergenerational income persistence (which indicates a lack of social mobility) is not necessarily a causal relationship. In this section, we elaborate on these points. Second, we discuss what measures of income inequality are likely most relevant to rates of upward mobility for low-income adolescents. Third, we explain how these observations might be relevant to the finding that social mobility rates do not appear to have fallen over recent decades. Fourth, we describe the cross-sectional relationship between income inequality and high school dropout rates. These discussions set the 
stage for us to then move on to a discussion of our proposed model characterizing the educational investment decision of adolescents.

\section{A. How Should We Interpret the Cross-Sectional Correlation between Inequality and Mobility?}

One of the fundamental tenets of empirical economics is that correlation is not causation.

As basic as this point is, it is one of which we often have to remind ourselves. For instance, in path breaking work on the measurement of mobility in the United States, Chetty, et al. (2014a) reports that the strongest correlates of high mobility areas are: (1) less residential segregation, (2) less income inequality, (3) better primary schools, (4) greater social capital, and (5) greater family stability. As an empirical statement of correlation, these are interesting findings. But, as the authors themselves emphasize, they are not indicative of causal relationships. They provide some insight to areas where further exploration should start, although not end, into the understanding the causal factors behind social mobility.

Unfortunately, in measuring outcomes that reflect economic disadvantage, many things are correlated, making it nearly impossible to determine what is actually driving those relationships. These correlations raise a lot of questions and possible explanations. As an example, a Brookings' sponsored Social Mobility Series on the Gatsby Curve contained a number of essays where authors offer other correlational observations as potential explanations for what is really "causing” low rates of upward mobility, including single parent households, the failure to adequately invest in early childhood education, the breakdown of civic institutions, cultural norms, and the like. The bottom line is that the evidence available to date provides documentation of a negative correlation between inequality and mobility along with a host of other things, all of which are interesting, but none of which pushes the bar in terms of what can 
be presumed to be causal. To inform public policy, though, we really need to know about causal pathways.

Furthermore, the negative correlation between inequality and mobility may simply reflect something about the composition of the population, as noted in Corak (2013). It may not be that one causes the other, but rather, both high inequality and low mobility reflect underlying population characteristics. Mankiw (2013) observes that low social mobility could occur even if there were equality of opportunity because of the inheritability of talent, intellect, and interpersonal skills. ${ }^{3}$ If the entire population had equal inherited skills, inequality would be low and mobility would be great because realizing higher or lower economic outcomes would be largely the result of chance. If, however, a population is comprised of individuals with a large degree of variation in talents and abilities, then we might expect both high inequality in income and high persistence in income between parents and children even in a full meritocracy. ${ }^{4}$ This interpretation of the relationship has drastically different policy implications than if the relationship reflects a causal relationship.

\section{B. What Is the Relevant Measure of Income Inequality for Upward Mobility Consequences?}

This paper is motivated to a large degree by the question of seemingly fixed differences across places. Why are some places consistently high inequality/low mobility and other places

3 Gary Becker and Richard Posner make the same point on their economics blog: http://www.becker-posner-blog.com/2013/01/meritocracies-and-intergeneration-mobilitybecker.html and http://www.becker-posner-blog.com/2012/12/meritocracy-social-mobilityintergenerational-mobilityposner.html.

${ }^{4}$ Mankiw makes this point clearly in a 2013 post on his widely-read blog by offering as an example the skill of chess players. If we have one group of chess players who are all of roughly comparable ability, then who wins and loses the matches will be closer to a random draw and mobility through the rankings will be high. If another group of chess players has some with greater ability and others who are weaker, then inequality in wins/losses will be higher and mobility lower. ("Observations on the Great Gatsby Curve," http://gregmankiw.blogspot.nl/2013/07/some-observations-on-great-gatsby-curve.html, accessed April 20, 2014.) 
consistently low inequality/low mobility? For example, New York and Washington D.C. consistently have high rates of income inequality (and low rates of economic mobility), while Minnesota and Utah do not. ${ }^{5}$ Taking an international perspective, year after year, the United States and the United Kingdom - generally low mobility countries --- have among the highest rates of income inequality among high-income countries, while Finland and Norway - generally high mobility countries -- tend to have low rates of income inequality.

This way of describing the situation makes it clear that we should be focused on longstanding differences in inequality, not year-to-year changes. In our conceptual framework and our empirical analysis, we focus on the permanent or semi-permanent economic and cultural landscape in the place where an adolescent lives, as opposed to short-term fluctuations. If a state experiences a temporary decrease in income inequality, it is unlikely, for example, that neighborhoods will change sufficiently quickly and sufficiently visibly that either economic opportunities or the perceptions thereof will be altered. We thus explicitly refer to income inequality as a "fixed” characteristic of a place and our empirical analysis reflects this.

Furthermore, as an empirical fact, there is much more cross-sectional variation in lowertail income inequality across states, as compared to within a state over time. In the income data we describe below, which represents the 1980, 1990, and 2000 Censuses, we find that the average standard deviation in the $50 / 10$ ratio across states (averaged over time) is 0.43 . Using the same data, we find that the average standard deviation in the 50/10 over time within a state (averaged across states) is much lower: 0.16.

\footnotetext{
${ }^{5}$ For instance, using data from the IPUMS Censuses, we have found that the correlation in the 50/10 ratio between the 1980 and 2000 Census years averages .74 across states (Kearney and Levine, 2014).
} 
Beyond the issue of permanent versus transitory, there is an important question about what is the most relevant inequality metric for economic mobility. We argue that the gap between the bottom of the income distribution and "middle class" is more relevant for the decisions of low-SES youth, than is the income gap at the top of the distribution. We are explicitly interested in upward economic mobility of low-SES children, and for children born into poverty or low-income families, we expect that their point of reference is more likely to be the middle of the distribution. If the Great Gatsby Curve captures behavioral effects associated with growing inequality and the likelihood of moving up the economic ladder for those near the bottom, we propose that the 50/10 ratio is the more relevant measure of income inequality. As our results below will show, the data support this supposition.

C. Why Don't Time Series and Cross-Sectional Patterns of the Inequality/Mobility Relationship Match?

The descriptive evidence on the relationship between income inequality and mobility presents something of a paradox. As we have described, there is a relationship in the crosssection (i.e., across space), but there does not seem to be a similar relationship across time. The overall rate of income inequality in the U.S. has generally been rising since the 1970s. If inequality causally led to a decrease in mobility, one would expect to see the increase in income inequality begin to appear in mobility trends at some point. In terms of our earlier discussion, one might expect continuing increases in income inequality increases over many years to eventually change the economic and cultural landscape in a way that would lead to an erosion of social mobility. But, recent evidence from Lee and Solon (2009) using the Panel Study of Income Dynamics (PSID) and Chetty, et al. (2014b) from linked parent/child tax records shows no reduction in social mobility in recent decades. Though that evidence is not the final word on 
the matter and critics have pointed out limitations, the finding that economic mobility does not appear to have fallen raises the question of whether inequality and mobility are causally linked after all.

These facts are documented in Figure 2, which report trend data on social mobility from Chetty, et al. (2014b) and Lee and Solon (2009) along with the trend in two measures of income inequality in the United States, the 90/50 ratio and the 50/10 ratio (which reflect ratios of different percentiles of the income distribution). The $\mathrm{x}$-axis in Figure 2 reflects the year in which income is measured for the 90/50 and 50/10 ratios. For the mobility measure taken from Chetty, et al. (2014b), year reflects birth cohort. For the mobility measure taken from Lee and Solon (2009), year reflects the year in which the son's income was recorded. Neither of the two mobility measures show any obvious trend in economic mobility in recent decades. In terms of income inequality, the top of the distribution has been pulling away from the middle. As shown in the figure, the 90/50 ratio has risen almost continuously over the past several decades. But, lower-tail inequality, as captured by the 50/10 ratio, has been roughly flat in recent decades. If our supposition is right that lower-tail inequality is more relevant to mobility than is upper tail inequality, this could help reconcile the apparent puzzle of rising income inequality and flat economic mobility. The fact that the 50/10 ratio is flat aligns with the flat mobility profile.

\section{How Does Income Inequality Relate to High School Dropout Rates?}

Though there is a vast economics literature examining potential explanations for the rise of income inequality over the past four decades, there remains an important need for more research on its social consequences. This is precisely what we are interested in exploring. In this paper, we are focused on whether there might be negative effects on educational outcomes for children born into low-income homes, which would then have implications for upward mobility. 
We start by looking at the aggregate relationship, just to see what that correlational relationship looks like.

Aggregate data show that places with higher levels of income inequality have lower high school completion rates. Figure 3 displays this relationship across states. For reasons described above, we focus on a long-term average measure of income inequality. We construct the ratio of household income at the $50^{\text {th }}$ percentile to the $10^{\text {th }}$ percentile, the " $50 / 10$ ratio," in each of the 1980, 1990, and 2000 Censuses, and for each state we use the average across Census years. We then compare that state-level measure to the state-level "dropout rate," which is 100 minus the four-year graduate rate. The correlation in these data is strong: places with higher levels of income inequality tend to have higher dropout rates. One quarter or more of those who start high school in Louisiana, Mississippi, Georgia, and the District of Columbia fail to graduate in a four year period, as compared to under 10 percent in Vermont, Wisconsin, North Dakota, and Nebraska. Lower-tail inequality is much greater in the former group of states.

Of course, many other things might be driving this relationship - including differences in the underlying characteristics of individuals living in these locations - so this is only meant to raise the possibility of a causal relationship; the plotted relationship can only be interpreted as correlational at this point. Our empirical analysis relies on individual level data, so that we are able to empirically control for individual level demographic characteristics as well as aggregate level differences across places. That allows us to pursue an empirical investigation of whether there is a causal link between aggregate level income inequality and individual level educational attainment.

\section{Motivating Framework: Modeling the Decision to Stay in School}

\section{A. A Stylized Model of the Decision to Drop Out of School}


We offer here an extremely stylized model of the decision to remain in school. This model is a straightforward adaptation of the model we laid out in Kearney and Levine (2014) to describe the decision of a young, unmarried women to delay childbearing. An individual chooses to drop out of school in the current period if the following condition is met:

$$
u_{o}^{d}+E\left(V^{d}\right)>u_{o}^{e}+E\left(V^{e}\right)
$$

where $u^{d}$ is current period utility if the student drops out and $u^{e}$ is current period utility if s/he remains enrolled. $V$ is the present discounted sum of future period utility; we assume $E\left(V^{e}\right)>$ $\mathrm{E}\left(\mathrm{V}^{\mathrm{d}}\right)$

If $u^{d}<u^{e}$, it is never optimal to drop out. But if $u^{d}>u^{e}$, which would be the case if the student experiences substantial utility costs from remaining in school (e.g. psychic costs), then that current period utility boost needs to be compared to the potential option value lost. Dropping out of school negatively affects expected future utility by leading to lower levels of consumption in the future. For simplicity, we characterize utility in future periods as taking high and low values, $U^{\text {high }}$ and $U^{\text {low }}$, respectively. We assume that dropping out reduces the likelihood of achieving $U^{\text {high }}$. We define $U^{\text {low }}$ to be the level achieved by a student who does drop out. The present discounted value of the future utility stream is thus deterministic and captured by $V^{\text {low }}$. If the adolescent remains enrolled, there is some positive probability $p$ that s/he will achieve the “high” utility position in future periods.

We can therefore write the condition to drop out of school as follows:

$$
u_{o}^{d}+V^{l o w}>u_{o}^{e}+p V^{\text {high }}+(1-p) V^{l o w}
$$

This condition indicates that the change in lifetime utility from staying in school comes from two opposite-signed sources: (1) the loss of current period enjoyment for staying in school and 
having restricted time for leisure and other activities and (2) a positive probability of achieving the high- utility state in the future. Rearranging terms, we see that a student will choose to remain enrolled if and only if:

$$
\left[p V^{\text {high }}+(1-p) V^{\text {low }}\right]-V^{l o w}>\left(u_{o}^{d}-u_{o}^{e}\right)
$$

Of course, the student does not perfectly observe $p$, as in Manski (1993). Instead, the student bases the decision on his perception of $p$, in particular, on his perception of his individual-specific $p$. Let us call this subjective probability of one's individual likelihood of success conditional on investment $q$. We would expect - though it need not be the case - that $q$ varies positively with actual returns as captured by $p$. So for example, increases in the actual return to schooling would lead to a greater perception of returns. But, there are external factors, call them $e$, that affect an individual's perceptions of his own likely returns to staying in school. These external factors could reflect influences throughout childhood or at any stage in a child's life.

For example, students who know few others who went to college may incorrectly assume that they wouldn’t benefit from college - “it's not for people like me.” In other words, for a given level of $p$, students of different socioeconomic backgrounds may differ in their individual value of $q$. In essence, we can think of $q$ as a function of $p$ and $e ; q=f(p, e)$. It is not our intention to empirically distinguish between the separate roles played by $p$ and $e$. Rather, we want to raise this conceptual possibility and note that income inequality might have an effect on perceived returns $q$, either through an effect on $p$ or $e$.

Incorporating this discussion, we can rewrite the condition for deciding not to drop out as follows: 


$$
q V^{\text {high }}+(1-q) V^{\text {low }}>V^{l o w}+\left(u_{o}^{d}-u_{o}^{e}\right)
$$

If an adolescent perceives that s/he has a sizable chance at achieving economic success -- and thereby capturing $V^{\text {high }}$-- by investing in education, the comparison is more likely to favor the choice "stay enrolled.” On the other hand, if the student perceives that even if s/he stays enrolled, his/her person-specific chances of economic success are sufficiently unlikely -- in other words, if $q$ is very low -- then the comparison is more likely to favor dropping out in the current period.

Rearranging expression [6], we can define a reservation subjective probability $q^{r}$ such that an individual will stay enrolled in school if and only if:

$$
q \geq q^{r}=\left(\frac{u_{o}^{b}-u_{o}^{d}}{V^{\text {high }}-V^{\text {low }}}\right) .
$$

We propose that one's perception of the likelihood of economic success, $q$, increases in socioeconomic status, such that $\frac{d q}{d(S E S)}>0$. Ikoma and Broer (2015) provide suggestive evidence based on tabulations of the nationally representative High School Longitudinal Survey (HSLS: 09) that is consistent with this proposition. T; they report that the overwhelming majority of $9^{\text {th }}$ graders aspire to go to college, but by $11^{\text {th }}$ grade, low SES students are substantially less likely to expect they will enroll in college, even among those students with high test scores. Their drop-off in aspirations/expectations is substantially greater than it is among comparable high-SES students with similar test scores.

We additionally propose that one's perceived probability of success is a function of the interaction of being low SES and inequality, such that $\frac{d q}{d(\text { ineq) }} \mid(S E S=l o w)<0$. That last proposition says that for an adolescent near the bottom of the income distribution, a greater gap 
between one's position and the middle of the distribution might have a negative effect on one's subjective $q$. If the middle class is sufficiently far from one's own experience, than the student's perceived returns to staying in school are low. Our main goal with the empirical analyses of the current paper is to determine whether there does appear to be an effect of income inequality on drop-out rates, conditional on rates of disadvantage and other relevant features of the aggregate environment. A secondary goal is to explore potential mechanisms that would be consistent with this line of inquiry, but we do not purport to exhaustively test for potential channels.

This framework has important implications for how to conduct our empirical analysis in terms of the appropriate level of geography. The way we are thinking about the possible effects of income inequality implies that the appropriate unit is a fairly broad area, such as a state or a Metropolitan Statistical Area (MSA). These would allow for the effects of any type of residential or institutional segregation that might occur as a result of widened income inequality and affect perceptions of success. If we were motivated by relative deprivation theories based on more localized comparisons, we would instead want to define income inequality much more locally.

\section{B. Income Inequality, Socioeconomic Status, and Lifetime Income}

The discussion above raises the question of whether low-SES youth from more unequal places actually do have a lower chance of earning higher levels of income later in life. Note that our framework does not require that to be the case, since an adolescent's decision is determined by $q(p, e)$, not just $p$, but it is still an interesting and relevant question to pursue. We offer two pieces of supporting evidence suggesting that this is indeed the case. 
First, in Kearney and Levine (2014) we examine data from the restricted-use 1979 National Longitudinal Survey of Youth Geocode data. ${ }^{6}$ We find that children who grow up in low-SES households and who live in a state with high lower-tail income inequality are estimated to have permanent incomes that are over 30 percent lower than similar children in low lower-tail inequality states (high and low inequality states are distinguished by a one point increase in the 50/10 ratio). If perceptions of economic success are gauged on actual outcomes, then these findings are consistent with our proposition.

Second, here we estimate "rates of return" to education to see whether the return is lower for low-SES youth in more unequal places. We are using the term "return" loosely here, as this analysis is not designed to isolate a causal effect. This is meant to be a suggestive exercise, not a definitive analysis of rates of return to education. Using data from the NLSY79 again, we track each respondent's average hourly wage from their primary job between 1998 and 2012 (all in 2015\$), which corresponds to the years when they would have been ages 34-55. We estimate regression models of the natural log of hourly wages on educational attainment (as measured in years) and demographic characteristics (race/ethnicity, gender, age), separately by SES status (as captured by mother's educational attainment category) and state-level income inequality (low, medium, and high).

The results, reported in Figure 4, indicate that among individuals living in low inequality states, the estimated return to an additional year of schooling is roughly constant across SES

${ }^{6}$ We distinguish youth respondents by their parents' educational attainment and define "permanent income" to be the average of all inflation-adjusted values of family income observed 15 or more years after the original 1979 survey, when youth respondents are in their late 20s or older. The sample used in that exercise includes all 8,226 respondents who lived with at least one of their parents at age 14 and who provided any income values in the 1994 survey or beyond. We assign the level of inequality to each respondent based on the respondents' 1979 state of residence. 
categories, averaging 10.5 to 11 percent. The estimated rate of return is lower, on average, for youth from all SES categories in high inequality states. However, that reduction in the rate of return is especially pronounced among low-SES children (those whose mothers dropped out of high school). Individuals born to low-SES mothers in high inequality states see an 8 percent rate of return to education, as compared to 10.6 percent for low-SES youth in less unequal states. To the extent that adolescents are basing their perceived likelihood of achieving economic success on actual rates, these data are consistent with a diminished perception of success among low-SES youth in more unequal places.

\section{Related conceptual models}

Our model is related to a set of models that emphasize the role of relative position in society in determining individuals' attitudes and behaviors. An influential theory in social science posits a role for relative deprivation - as distinct from absolute deprivation - in leading to acts of social unrest. In the economics literature, Luttmer (2005) conducts an empirical investigation of this idea and documents that people are less happy when they live around other people who are richer than themselves. In the field of psychology, Destin, Richman, Varner, and Mandara (2012) provides evidence that students who perceive themselves to be of lower social status (within a high school setting) suffer worse emotional distress which has negative consequences on their academic performance. The authors conclude that "students' perception of their location on a relevant social hierarchy is related to their emotional state, academic behaviors, and academic achievement in such a way that it could reinforce the stability of their current location on the hierarchy." Along these lines, the relative position of individuals could lead to feelings of alienation from society that lead them to want to engage in rebellious types of behaviors, perhaps including dropping out of school. 
Genicot and Ray (2014) propose a theoretical model that leads to the same prediction as our “economic despair” model. Their model proposes that society-wide economic outcomes affect individual aspirations. Aspirations that are slightly above one’s position lead to increased human capital investment; but if aspirations get too far from one's current position, that could lead to frustration and lower levels of human capital investment.

Watson and McLanahan (2011) present evidence that relative income matters for the marriage decision of low-income men. They interpret their model within the framework of an identity construct, based largely on the identity model of Akerlof and Kranton (2000). Specifically, Watson and McLanahan hypothesize that individuals perceive a threshold income required for marriage, and that this threshold is influenced by an individual's local reference group. One could imagine an extension of this theory that applies to educational attainment. Perhaps individuals perceive a threshold type of person who completes higher levels of education; youth at the bottom of the income distribution in more unequal places may be more likely to view themselves as the low achievers in their reference group.

All of these perspectives describe a potential mechanism linking high inequality to lower rates of high school completion. They are useful because they offer a conceptual framework for thinking about the issue, and a useful framework to guide the empirical analysis and interpretation of results. We are ultimately unable to perform a rigorous econometric examination of this hypothesis, though, as reliable measures of perceptions and attitudes with detailed demographic and geographic information are not available to us.

\section{EMPIRICAL STRATEGY}

\section{A. Model Specification}


The goal of our econometric analysis is to determine whether individuals from disadvantaged backgrounds who live in areas with high rates of income inequality experience greater high school dropout rates. We estimate individual level regressions that model an individual's educational outcome as a function of individual level characteristics (including SES status), state and year fixed effects, and, crucially, the interaction of SES status and the level of inequality in the place in which that individual lives. It is that interaction term that gives us the main coefficient of interest and indicates whether low SES youth in high inequality locations are relatively more likely to drop out of high school.

The formal econometric model takes the following form:

$$
\begin{aligned}
\text { Outcome }_{i s c}= & \beta_{0}+\beta_{1}\left(I_{s} \cdot L S_{i s}\right)+\beta_{2}\left(I_{s} \cdot M S_{i s}\right)+\beta_{3} L S_{i s}+\beta_{4} M S_{i s} \\
& +\beta_{5} X_{i s}+\beta_{5} E_{s c}+\gamma_{s}+\gamma_{c}+\varepsilon_{i s c}
\end{aligned}
$$

where the outcome is some measure of educational attainment (mainly high school dropout, but also GED, or high school graduate in some specifications), I is our measure of income inequality, LS and MS are indicators of low and middle SES, respectively. The subscripts $i, s$, and $c$ index individuals, states, and birth cohorts, respectively; $\gamma_{s}$ and $\gamma_{c}$ represent state and cohort fixed effects. Cohort variation comes from the different datasets. The vector $X$ consists of additional personal demographic characteristics - gender, race/ethnicity, and an indicator for living with a single parent at age 14 . The vector $E$ captures environmental factors including relevant public policies and labor market conditions in the state and year in which the respondent was age $16 .^{7}$

\footnotetext{
${ }^{7}$ These variables include the state unemployment rate at age 16 , the state minimum wage, state education policies (compulsory schooling age and indicators for high school exit exam requirements), state welfare policies (family cap and maximum AFDC/TANF benefit for a family of 3), state abortion policies (Medicaid funding, parental notification/consent, and mandatory delay laws), and an indicator variable for SCHIP implementation and Medicaid family planning waiver implementation. Information on exit exam requirements by state and year is taken from Dee and Jacob (2007) and Center on Education Policy (2010). Information on
} 
We have specified this model focusing on state-level variation, but we also consider variation at the MSA level as well.

It is important to note that our measure of income inequality is a long-run average (not subscripted by $c$ ), so we are estimating the impact of persistent differences in inequality, not transitory differences. This contrasts with a more typical panel data approach exploiting transitory variation in the explanatory variable of interest. For example, Mayer (2001) uses the 1993 PSID data to exploit over-time variation in state-level income inequality, as measured by the Gini coefficient, to investigate whether state/year levels of income inequality affect individual level educational outcomes. In her regression models that include both state and year fixed effects, there is no evidence of a statistically significant relationship. We do not find this to be surprising, as it would be quite remarkable for year-to-year fluctuations in income inequality to translate into changes in institutions, norms, or attitudes such that educational outcomes responded at such a fine interval of time.

The main shortcoming with this empirical strategy is that any omitted, state-specific factor that is fixed over time and correlated with long-term measures of income inequality may generate biased results if it has disproportionate impacts on the educational attainment of low SES youth. To determine whether potential confounders are playing this role, we estimate a series of "horserace" regressions of the following form:

$$
\begin{aligned}
\text { Outcome }_{i s}= & \beta_{0}+\beta_{1}\left(I_{s} \cdot L S_{i s}\right)+\beta_{2}\left(I_{s} \cdot M S_{i s}\right)+\beta_{3}\left(A_{s} \cdot L S_{i s}\right)+\beta_{4}\left(A_{s} \cdot M S_{i s}\right) \\
& +\beta_{5} L S_{i s}+\beta_{6} M S_{i s}+\beta_{7} X_{i s}+\beta_{8} E_{s}+\gamma_{s}+\gamma_{c}+\varepsilon_{i s}
\end{aligned}
$$

compulsory school laws by state and year are obtained from the National Center for Education Statistics, Digest of Education Statistics (various years). Detailed source information and notes about the construction of the other variables in this list are provided in Kearney and Levine (2012). We have also experimented with interacting all of the policy variables with SES indicators and found that the results were unaltered by doing so. In addition, we include dummy variables indicating the dataset that the observation came from. 
In essence, our approach involves including potential alternative state factors $\left(A_{s}\right)$ that could plausibly affect the relative educational attainment of low SES youth and examining whether the results change when we include them in the same manner in which we have included the inequality/SES interactions. If the coefficients on the interaction terms of primary interest change when we add the additional interactions between SES and these alternatives, then it would suggest the results generated from equation (1) are biased estimates of the causal effect of inequality. It is impossible to rule out this form of bias unless we try including every possible alternative, but if what we believe to be important alternatives have no impact, then we can be more confident in a causal interpretation of our findings.

We consider four categories of these other state factors. The first set of factors addresses the measurement of income inequality. As noted earlier, we use the 50/10 ratio as our primary measure of inequality. In our past work on early, non-marital childbearing, we found that the 50/10 ratio was the most empirically relevant measure to determining rates of early, non-marital childbearing. But, we recognize that there are reasons why upper tail inequality might be particularly important for educational outcomes. We empirically explore the impact of including the $90 / 50$ ratio, as well as the $10^{\text {th }}$ and $50^{\text {th }}$ percentiles of the income distribution on their own. ${ }^{8}$

The second set of alternative factors we consider are measures of the wage returns to education. This is important because it enables us to identify the incentive effect of higher returns (as in a standard Becker model) separately from any offsetting discouragement effect of the type we propose. Third, we consider a set of alternatives that could be considered mediating factors to determine the mechanism by which increased inequality alters educational attainment.

\footnotetext{
${ }^{8}$ A possible concern is that inequality ratios are driven by persistent high school graduation rates in a place, which would induce an endogeneity problem with this specification. To address that possibility, we reran our regression analyses with 50/10 ratios constructed just among high school graduates. This analysis yielded similar findings to those reported below.
} 
Fourth, we include a set of potential confounding factors that might lead to omitted variable bias if not explicitly interacted with SES status and included in the model. A final set of regressions are estimated to determine the extent to which differences in distributions of underlying ability would alter the interpretation of our findings.

B. Data

To estimate these models, we use five sources of individual-level data. Three of the sources are obtained from the National Center for Education Statistics (the National Educational Longitudinal Survey - NELS, High School and Beyond - HSB, and the Educational Longitudinal Survey - ELS) and the other two are the 1979 and 1997 cohorts of the National Longitudinal Survey of Youth (NLSY79 and NLSY97). ${ }^{9}$ Each of these datasets has the distinct advantage of including detailed measures of educational attainment, including the ability to separately identify those who receive a degree through passing a general educational development (GED) test and those who receive a traditional high school degree. Their combination also generates a sample of tens of thousands of teens who are moving through (or just recently completed) their high school years. The NLSY79 originally surveyed 12,686 respondents born between 1957 and 1964 (age 14-22 in 1979). HSB originally surveyed over 30,000 high school sophomores in 1980, of whom around half were invited to participate and

\footnotetext{
${ }^{9}$ For all datasets other than High School and Beyond, geographic identifiers are only available for those with restricted use data agreements. This means that we are not able to share our data with other researchers, although we are happy to provide our programs so that those who are able to obtain their own agreement can follow our steps. Formal state identifiers are not available at all for High School and Beyond, but researchers have identified ways to provide educated guesses of state of residence for survey respondents (cf. Grogger, 1996). We are grateful to Jeff Grogger for providing us with his data indicating state identifiers for these data.
} 
13,682 of whom did so in the second follow up four years later. ${ }^{10}$ We measure high school completion in that year. NELS surveyed $14,9158^{\text {th }}$ graders in 1988 who were also surveyed in 1994, when we can determine whether they completed high school. NLSY97 surveyed 8,984 respondents born between 1980 and 1984 (age 12-18 in 1997). ELS surveyed 15,300 $10^{\text {th }}$ graders in the spring of 2002 who were also surveyed in 2006, when high school completion can be measured. In combination, a maximum of 65,567 respondents are available. In reality, mainly because of missing state identifiers, missing information regarding SES (defined below as level of maternal education), and sample attrition we have available 53,150 teens for our analysis. ${ }^{11}$ Limited time variability is available when we combine these datasets, but our analysis relies on long-term geographic variability, as we described earlier.

A critical feature of these data, as captured in our econometric models, is a measure of the youth's socioeconomic status. The measure that is available in each of these datasets is mother's level of education. We distinguish students according to whether their mother dropped out of high school, graduated from high school, or attended college (regardless of their graduation status). Although maternal education does not perfectly predict economic status, we take advantage of the fact that it is strongly correlated with SES.

Although the availability of all five of these datasets provides a unique opportunity to generate a large sample of high school students and follow them through the completion (or not) of their degree, their combination also presents challenges. In particular, identifying a consistently selected sample and outcome measure is somewhat complicated. Sample selection is

\footnotetext{
${ }^{10}$ This survey also included over 28,000 seniors in 1980, but we do not use them because many high school dropouts never make it to be seniors in high school; using these data would introduce substantial selection bias.

${ }^{11}$ Sample attrition reduces the sample size to 61,067. Missing educational attainment reduces it further to 59,286. Missing maternal education brings the final sample size down to 53,150.
} 
an issue because individuals entered the samples at different ages and grades. For instance, the NELS initially surveyed $8^{\text {th }}$ graders and the ELS and HSB initially surveyed $10^{\text {th }}$ graders. Survival to $10^{\text {th }}$ grade represents a degree of success that changes the composition of the sample since more poorly performing students may drop out before they make it to $10^{\text {th }}$ grade. We discuss issues like these in the attached data appendix; we account for this in our econometric specification by including data set dummy variables, which we have labeled in the model as cohort fixed effects since datasets identify cohorts. We focus on three consistent measures of educational attainment across datasets. In each of these datasets, we are able to determine (a) whether a student completed high school and received a traditional diploma, (b) whether the student received a GED, or (c) whether the student never obtained a high school degree via either route.

Our measures of income inequality are defined over pre-tax, post-transfer household income using microdata from the 1980, 1990, and 2000 Censuses. These datasets are available from IPUMS-USA (Ruggles et al., 2010); they capture details of the income distribution over a comparable period as our microlevel datasets. We take one observation per household, adjust the data for inflation to denominate dollars in a common year, calculate relevant percentiles of the income distribution (unweighted), and then define state/year level income inequality ratios (the $50^{\text {th }}$ to the $10^{\text {th }}$ and the $90^{\text {th }}$ to the $50^{\text {th }}$ ) based on those data. ${ }^{12}$ We exclude those residing in group quarters, but we impose no other sample restrictions.

\footnotetext{
${ }^{12}$ Total household income in the census is defined as the sum of eight categories: Wages, salary, commissions, bonuses, or tips from all jobs; Self-employment net income; interest, dividends, net rental income, royalty income, or income from estates and trusts; Social Security or Railroad Retirement; Supplemental Security Income (SSI); any public assistance or welfare payments from the state or local welfare office; retirement, survivor, or disability pensions other than social
} 
We then take the long-term average over all years for a state. As we described earlier, we take this approach because we are trying to capture something about the permanent or semipermanent economic and cultural landscape in the place where an adolescent lives, as opposed to short-term fluctuations. Simple correlations across states in state-level income ratios between the three Censuses are high, supporting this approach. For instance the correlation across states in the 50/10 ratio between 1980 and 1990 and between 1980 and 2000 are 0.81 and 0.74 , respectively. Correlations in the 90/50 ratio are even higher. Moreover, the 50/10 ratio has been largely stable over time, as simple transformations from published Census Bureau data indicates. $^{13}$

\section{EMPIRICAL RESULTS}

\section{A. Descriptive Analysis}

To highlight the identification strategy that we use, we initially present the results of a descriptive analysis of educational outcomes for teens by their socioeconomic status and the level of income inequality that exists in their state. Figure 5 presents the results of this descriptive analysis. Foreshadowing the results from our subsequent formal econometric analysis, we present these results just for boys. We classify states into those in the top, bottom and middle two quartiles of inequality as measured by the 50/10 ratio. ${ }^{14}$ The bars represent the

security; any other sources of income received regularly such as Veterans' (VA) payments, unemployment compensation, child support, or alimony.

13 See the data available at https://www.census.gov/hhes/www/income/data/historical/inequality/table_IE-1A2.pdf (accessed $11 / 18 / 2014$ ), which provide the relevant percentiles necessary to construct the income ratios.

${ }^{14}$ States fall into the following categories (with the 50/10 ratio in parentheses). Low inequality: UT (3.40), NV (3.49), VT (3.54), ID (3.59), NH (3.61), NE (3.71), IA (3.72), WI (3.72), AK (3.75), OR (3.77), WY (3.78), ME (3.80), IN (3.80). Middle inequality: CO (3.81), AZ (3.81), ND (3.82), HI (3.82), SD (3.84), FL (3.85), MT (3.86), DE (3.87), KS (3.88), MN (3.90), WA 
percentage of boys who dropped out of high school. Boys are separated into categories according to their mother's educational attainment to proxy for the SES, along with the level of inequality that exists in their state.

The figure groups SES categories so that the pattern in educational outcomes by inequality status within SES category is readily apparent. We see that around 5 percent of boys from higher SES families drop out of high school regardless of the level of income inequality in their state. No obvious pattern is evident among the middle SES boys in different inequality categories either. Among low-SES boys, however, higher inequality is associated with higher rates of dropping out of high school. The magnitude of the difference is sizeable. Low-SES boys in high inequality states are almost 6 percentage points more likely to drop out of high school than low-SES boys in low inequality states.

\section{B. State-Level Analysis}

These findings from our descriptive analysis are affirmed when we estimate the regression models described in equation 1 . In essence, these regressions are analogous to the data reported in Figure 5 with the exception that the 50/10 ratio is treated continuously rather than in categories and additional explanatory variables are included. Table 1 presents those results for all students in the sample and then separately for boys and girls. ${ }^{15}$ Columns 1 through 3 are identical except they focus on our three different measures of educational outcomes (high school dropout - Column 1; GED - Column 2; and high school graduation - Column 3). The percentage of

(3.92), MD (3.98), VA (4.03), PA (4.03), CT (4.06), MO (4.07), OH (4.08), CA (4.15), OK (4.19), NC (4.19), NM (4.21), NJ (4.22), MI (4.22), WV (4.25), AR (4.28). High inequality: IL (4.29), RI (4.38), TX (4.40), TN (4.44), SC (4.45), MA (4.52), KY (4.54), MS (4.59), GA (4.66), NY (4.77), AL (4.85), LA (5.03), DC (5.66).

${ }^{15}$ We have also estimated these models separately by race and ethnicity, but the data were not sufficiently powerful to yield statistically significant differences across groups. 
students in each category is displayed just above the regression results to aid in interpretation. When we focus on dropping out of high school for all students (the top panel of the table), we see that a one point increase in the 50/10 ratio increases the likelihood of dropping out by 2.3 percentage points for students from low-SES families. This estimate is not quite statistically significant, with a p-value of 12.3 percent. When we explore differences in estimates by gender, however, we see that boys, in particular, are more likely to drop out of high school when they grow up in a low SES household in an area marked by high inequality. Moving from a relatively low inequality to high inequality state represents a one point increase in the 50/10 ratio. This means that making such a move for a boy from a low SES family increases the likelihood of dropping out of high school by age 20 by 4.1 percentage points. The analogous estimate for girls is considerably smaller, statistically insignificant, and marginally significantly different than the estimate for boys (p-value $=8.6$ percent). Estimates for the other two outcomes, receiving a GED or graduating from high school, are too imprecise to determine whether the increase in dropping out for boys came mainly from either of them.

C. MSA-Level Analysis

In the next set of regressions we examine what happens if we run the main analysis at the level of MSA, instead of state. For some large states, for example, California or Texas, the MSA may be the more relevant level of geographic boundaries to define economic conditions and institutions.

Table 2 focuses on the outcome of dropping out high school and repeats the analysis of the impact of inequality and mobility by MSA rather than state. The models reported here are analogous to those in Table 1 except that these regressions exclude policy variables set at the state level. Omitting those variables from the state-level models has virtually no impact on the 
results. We are also forced to omit the NELS and HSB data from our analysis because we are not able to identify geography below the state-level in the base year in those data sets. MSA-level results are similar to state level results. Lower SES teens, and particularly boys, who grow up in MSAs with greater lower-tail income inequality are considerably more likely to drop out of high school. The p-value on the gender difference in impacts on dropping out of high school is 0.0004. The general pattern in the data showing that boys' drop out rates are more likely to be affected by inequality than girls leads us to focus the remainder of the analysis on boys. We also focus the remainder of our reported results solely on the outcome of dropping out of high school.

\section{AN EXAMINATION OF POTENTIAL EXPLANATIONS}

In the next set of tables, we estimate models of the form of Equation 2 that are designed to examine the extent to which other state-specific factors may matter and alter our interpretation of a causal impact of income inequality. In each of these tables, we also include the results of our base specification from Table 1 in the first column to facilitate comparison.

\section{A. Alternative Measures of the Income Distribution}

Table 3 reports the results of estimating the main equation of interest using different measures of the income distribution. The alternatives we consider are the 90/50 ratio, the $10^{\text {th }}$ and $50^{\text {th }}$ percentiles of the income distribution, separately, and the share of income going to the top one percent of households. Data on the share of income going to the top one percent of households was obtained from an online appendix to Chetty, et al. (2014a). Those data are available at the level of commuting zones. We aggregated them to the state level. Each of the alternative measures of the income distribution capture different attributes. The 90/50 ratio represents income inequality at the top of the income distribution. This is the part of the distribution that has grown over time. We have argued that the 50/10 ratio is a better measure of 
inequality for the low SES population because it may more realistically indicate what is available to them if they were able to move up the ladder, but this is an empirical question. We also include the $10^{\text {th }}$ and $50^{\text {th }}$ percentiles of the income distribution separately to understand whether our findings based on their ratio are actually attributable to one of the two components separately. The income share going to the top one percent addresses the impact of very high end inequality.

As described earlier, we include the interaction of the 50/10 ratio and SES status along with interactions between SES status and these other measures. The estimates reported in Table 3 provide support for the notion that the 50/10 ratio is the relevant measure of income inequality for the outcomes of low-SES boys. Interactions with the other measures are generally statistically insignificant and have no impact on the estimated effect of the interaction between the 50/10 ratio and low SES. If anything, including the 90/50 ratio strengthens the relationship between the 50/10 ratio among low-SES boys and dropping out of high school.

\section{B. The Role of Wage Inequality}

Recall from our earlier discussion that if greater inequality reflects a greater return to investment in human capital, the Beckerian framework predicts that all else equal, students should invest more when income inequality is greater. Solon (2004) formalizes this concept in a model where parents make human capital investments in their children; ${ }^{16}$ building on the theoretical foundation of Becker and Tomes (1979), he shows that parental investment in a child's human capital increases when the payoff to that return is higher, that is, when there is

\footnotetext{
${ }^{16}$ We are agnostic as to whether this decision ultimately rests with the adolescent, his parent, or some combination thereof.
} 
more wage inequality. In our framework this would entail a reduction in the likelihood of dropping out of high school. ${ }^{17}$

The specifications reported in Table 4 address this possibility directly by considering a distinct offsetting role from the incentive effect of wage differentials. In Column 2 we estimate a regression model that includes separate interaction terms for low SES and (a) lower-tail inequality and (b) the wage premium for high school graduates relative to high school dropouts. The high school graduate wage premium is calculated from the same Census data that we used to estimate measures of inequality except that the sample is restricted to those between ages 21 and 64.

The results of this specification indicate that, even with this additional interaction term in the model, the point estimate on the interaction term between low-SES status and lower tail inequality is virtually unchanged from the initial specification. The data indicate a positive effect of income inequality on the likelihood that a disadvantaged youth drops out of school, conditional on the high school wage premium. The high school graduate to dropout wage premium itself is estimated to reduce the likelihood of dropping out for low-SES boys, although it is insufficiently precise to be statistically significant.

\footnotetext{
${ }^{17}$ Although our analysis focuses on cross-sectional variation, our framework also yields some potential insights regarding trends in educational attainment over time. Despite the growing return to education that has been taking place over time, the high school dropout rate has been roughly constant, until, perhaps, recently (Goldin and Katz, 2010). According to our theoretical framework, increased educational incentives associated with higher educational wage premiums may be counteracted with a greater "desperational effect" associated with growing income inequality, generating an ambiguous prediction regarding educational attainment. As noted above, though, the 50/10 ratio has been relatively flat over the past few decades, which is consistent with generally unchanged rates of dropping out of high school in our framework.
} 


\section{Residential Segregation and Other Potential Mediating Factors}

There are a number of pathways through which income inequality could hinder the educational attainment of disadvantaged students. In the introduction chapter of the edited volume Whither Opportunity, Duncan and Murnane (2011) discuss the possibility that income inequality has an effect on neighborhoods, families, labor markets, and the educational system in ways that affect educational outcomes. ${ }^{18}$ In this section we empirically examine factors along these lines. We begin with measures of residential segregation. To the extent that higher income inequality is associated with increased residential segregation - as empirically demonstrated by Watson (2009) - this could be a pathway through which income inequality affects the educational attainment of disadvantaged youth. Greater residential segregation can affect social and labor market networks, the presence of high achieving role models, and the establishment of peer groups and norms.

The influential work of Wilson (1987) emphasizes the role of "social isolation" in driving rates of urban joblessness and non-marital childbearing. He hypothesizes that the lack of exposure to mainstream middle class role models plays an important role. Case and Katz (1991) provide an early example of non-experimental empirical research suggesting significant neighborhood peer effects for criminal behavior as well as the likelihood that youth are out of

18 Chetty and Hendren (2015) shows that low-income children who move to a "better" neighborhood, as measured by the outcomes of those children already living there, experience improved outcomes themselves, with those moving at a younger age experiencing greater gains. They use methods including sibling differences and family fixed effects to provide statistical identification and they show that these childhood moves generate greater gains when their new community is characterized by less concentrated poverty, less income inequality, better schools, a larger share of two-parent families, and lower crime rates. This part of the analysis, however, does not attempt to determine which, if any, of these place-based characteristics have a causal relationship with child outcomes later in life. Nor does it attempt to figure out whether income inequality, per se, has a negative effect on the outcomes of low-income children, and if so, through what mechanisms. 
school and out of work. The widely studied Moving to Opportunity for Fair Housing (MTO) demonstration - run by the U.S. Department of Housing and Urban Development - was predicated on the notion that helping low-income families move out of high-poverty neighborhoods would yield measurable economic self-sufficiency benefits. ${ }^{19}$

To investigate neighborhood segregation as a mediating channel, we incorporate into our empirical model indices of racial segregation, income segregation, and poverty segregation. To the extent that any of these factors, when interacted with SES, have a statistically significant effect and/or alter the estimated impact of the SES*50/10 ratio interactions, one could conclude that they are important mediating factors. We obtain the three segregation measures from the online data appendix to Chetty et al. (2014a,b). The racial segregation measure is a multi-group Theil Index calculated at the census-tract level over four groups: white alone, black alone, Hispanic, and other. The income segregation measure is calculated as a rank-order index by Census tract using the definition laid out by Reardon (2011). ${ }^{20}$ The poverty segregation index captures the extent to which individuals in the bottom quartile are segregated from those above the 25th percentile. We have averaged these commuting zone measures up to the state level (population-weighted) for our state-level analysis. So, for example, a state like Texas (with

\footnotetext{
${ }^{19}$ We describe the findings of that experiment, and how they relate to our findings, in our discussion section below.

20 The income segregation measure captures the extent to which households of different income percentiles are evenly distributed among residential locations. For example, if 10 percent of a Census tract is below the 10th percentile, that indicates no segregation at that level. The overall statistic essentially calculates this for all 100th centiles and then aggregates up, putting more weight near the middle of the distribution where there should be more equality. The segregation index is maximized if and only if there is no variation in income within any neighborhood. The segregation index is minimized if and only if within each neighborhood, the income distribution is identical to that in the population. This Reardon (2011) measure has the desirable property that it is insensitive to rank-preserving changes in the income distribution.
} 
highly segregated commuting zones) will be classified as highly income segregated and Utah will not.

The results reported in Table 5 provide no evidence of this sort of effect. None of the coefficients on the interactions with these factors in columns (2) through (4) are statistically significant, and their inclusion has a negligible impact on the SES*inequality interactions. The lack of support in the data for these factors is noteworthy, but we hasten to note that it should not be interpreted as definitive evidence against an important role for residential segregation in affecting the educational outcomes of poor youth. Rather, these regression results imply that the average level of segregation in the state is not driving the empirical relationship we find between state level income inequality and individual-level education outcomes.

Another potential mechanism through which income inequality might affect the drop-out rates of low-SES youth is through reduced public provision of educational inputs. Political economy considerations of whether higher levels of income inequality would lead to lower levels of public goods provision (including public school expenditures) is actually ambiguous. More money in the hands of the rich may reduce transfers of resources to the poor. Alternatively, if the rich become more fearful about the poor agitating for social change, it may increase transfers. Furthermore, under the median voter model, with greater inequality, the median falls relative to the mean, and the preferences of the median voter for more distribution from the rich prevail. Recent empirical evidence on the relationship between income inequality and public revenue for school spending finds public school spending increases as the level of local income inequality rises (Boustan et al. 2013; Corcoran \& Evans, 2010; Gordon, 2013). Nonetheless, we run the relevant regression to investigate public school expenditures as a mediating pathway. 
Table 6 reports the results from regression that includes the interaction of state-level 50/10 inequality and educational inputs. Educational inputs are measured by per capita educational expenditures and pupil-teacher ratios. ${ }^{21}$ In our data, we see that per capita educational expenditures and pupil teacher ratios are only weakly correlated with state-level lower-tail income inequality ( 0.14 and -0.23 , respectively), making it unlikely that these are omitted variables driving the observed link between income inequality and drop-out behavior. The regression results confirm that this is not the case. The data do not indicate a direct effect of these measures on the rate at which low-SES individuals drop out of high school. Nor does the inclusion of these measures alter the conclusion that greater lower-tail income inequality leads to higher rates of high school drop-out behavior among low SES individuals.

Table 6 also considers aggregate levels of social capital and family structure as potential mediating factors. Social capital is a measure introduced by Putnam (2000) that combines voter turnout rates, the fraction of people who return their census forms, and measures of participation in community organizations. ${ }^{22}$ Family structure is measured by the fraction of children living in single parent households. Although social capital and the fraction of children living with single parents are more strongly correlated with our measure of income inequality, including those variables in the model similarly has little impact. Ultimately, the data fail to provide evidence that any of these potential factors are the mediating mechanism driving the empirical relationship we document.

\footnotetext{
${ }^{21}$ We thank Liz Cascio for generously sharing the historical data she compiled on per pupil expenditures and per pupil teacher ratios.

${ }^{22}$ We obtained these data and the fraction of children with a single parent from the online appendix to Chetty, et al. (2014a).
} 


\section{Remaining Potential Confounding Factors}

In the last set of "horse race" specifications, Table 7 presents the results of including one additional set of interactions with other state-specific factors that could simply represent confounding factors. These include the percentage of the state's population that is minority, the poverty rate in the state, and the state's incarceration rate, and the fraction of employment in the manufacturing sector. ${ }^{23}$ The goal here is to determine whether one of these state-specific factors is a contextual factor related to state-level income inequality and driving the differential high school dropout rates. The results reported in Table 7 do not indicate that to be the case. Interactions between each of these factors and socioeconomic status are universally insignificant and their inclusion in the regression model has no substantive impact on the estimated effect of the interactions between lower-tail inequality and individual SES. ${ }^{24}$

\section{E. The Role of Underlying Differences in Ability}

${ }^{23}$ The incarceration data are compiled by the U.S. Bureau of Justice Statistics, Office of Justice programs, downloaded from www.ojp.usdoj.gov. Poverty rate data comes from the United States Census Bureau and were downloaded from http://www.census.gov/hhes/www/poverty/data/historical/people.html.

We obtained the manufacturing data from the online appendix to Chetty, et al. (2014a).

${ }^{24}$ We have also estimated many of the horse-race specifications at the level of MSA and confirmed that defining the geographic area at this level does not alter the qualitative results. Not all alternative characteristics considered in the main state level regressions are available at the MSA level. Appendix Table 1 reports results from including the interaction of SES status with alternative measures of the income distribution. Appendix Table 2 reports results from including the interaction of SES status with segregation measures. Appendix Table 3 reports results from including the interaction with fraction single-parent and the fraction employed in manufacturing. The results correspond to the results from the state level regressions: the estimated coefficient on the 50/10 interaction is not qualitatively changed from the addition of the new interaction. Furthermore, in all regressions but one, the estimated coefficient on the added interaction term is not statistically different from zero. The one exception is for the interaction of low-SES*racial segregation measured at the MSA level. In this regression, MSA-level racial segregation appears to be positively related to drop out rates. Future work should pursue an investigation of mechanisms and look at different levels of geography. For the purposes of the present paper, the finding is upheld that there is an empirical relationship between lower-tail inequality and the likelihood that a low-SES boy drops out of school, and that does not appear to be driven by confounding factors at the aggregate level. 
As described earlier, a potential alternative explanation for the link between high inequality and low mobility is that in locations with greater demographic diversity, there will be a mechanical correlation that links the two. The more similar the underlying populations, the lower the inequality (by definition) and the greater the mobility because chance will play a greater role in determining who succeeds in any given period. In essence, this is an argument about the underlying distribution of "ability.”

We explore this alternative within the context of educational outcomes using test scores as a proxy for underlying ability. Specifically, we use data from scores on the Armed Forces Qualifying Test (AFQT), which was administered to participants in the NLSY79 and NLSY97 surveys. The AFQT is used by the military to determine eligibility and placement. The score is reported as a standardized percentile ranking. These data have been used by empirical researchers in the past for similar purposes (e.g., Herrnstein and Murray, 1994; Neal and Johnson, 1996; Belley and Lochner, 2007). We hasten to note that the AFQT is not a direct measure of innate ability; on this point, Cascio and Lewis (2006) show that exogenous increases in educational attainment lead to increases in AFQT scores, especially for minorities. It is most appropriately considered a cumulative measure of ability, reflecting innate endowments, environmental influences, and the result of formal and informal human capital investment. Still, these test scores provide information about cognitive ability at the time the exam was taken.

The purpose of the empirical analysis reported in Table 8 is to determine whether these differences in the AFQT measure of cognitive ability can explain any share of the greater relative rate of drop out behavior among low-SES boys in high inequality places. As in past tables, the first column is included for the purpose of comparison; it reports the results from a model analogous to our main specification taken from Table 1 for boys, with the estimated point 
estimate on the interaction of primary interest being 0.042 (standard error 0.016 ). ${ }^{25}$ Since the AFQT is only available in NLSY79 and NLSY97, the second column presents the same regression just for those two datasets. The results indicate a somewhat larger point estimate (0.067), for the effect of inequality on dropping out, but the smaller sample size leads to greater imprecision as well (standard error 0.029). The third column of this table examines what happens if we control for AFQT as an explanatory variable in a specification that is otherwise identical to that in Column 2. We find that doing so does reduce the point estimate by about one-third, to 0.045 from 0.067 . This is not statistically different from the estimated effect in column one, but the standard error is now 0.028 (owing to the smaller sample size coming from having to restrict the analysis to just two datasets), and so this estimate is no longer statistically significant from zero.

In Column 4, we treat AFQT as the dependent variable and estimate a model that is otherwise equivalent to those estimated earlier. The point estimates indicate that low-SES youth in high inequality areas have lower AFQT scores; that relationship is marginally statistically significant $(p$-value $=8.3$ percent). This result helps explain why the estimated impact of inequality for low-SES boys fell when we added AFQT: it appears that low-SES boys who live in high inequality locations have AFQT scores that are even lower than those for low-SES boys overall. $^{26}$

\footnotetext{
${ }^{25}$ The only minor difference between this specification and that in Table 1 is that we omit all policy variables since we will subsequently be restricting the sample to just two datasets leaving us with very limited variation across states over time. As the results indicate, dropping those variables has virtually no impact on the findings.

${ }^{26}$ Multiplying the point estimate of -4.38 from the low-SES interaction term in column (4) with the point estimate of -0.005 on the AFQT variable from column (3) yields 0.022 , suggesting that the lower AFQT scores of boys in high inequality states would lead to a 0.022 percentage point relative increase in drop-out rates, which is exactly the difference we see between columns (2)
} 
There are two possible interpretations of these results. For readers inclined to interpret the AFQT as measuring innate ability, one could conclude that the exclusion of the AFQT variable in previous analyses leads to an upwardly biased estimate of the causal impact of inequality on dropout rates; still, two-thirds of the effect remains. An alternative interpretation is that part of the effect of income inequality is captured by decreased educational investment before the actual drop out event. This corresponds to a leading view of drop out behavior as a "process" rather than a discrete event: a student begins to demonstrate irregular attendance, then multiple failed courses, and eventually the obstacles to graduation feel overwhelming and the student drops out (Rumberger, 2011). In other words, discouraged students stop applying themselves early. This could show up as a lower AFQT score, consistent with the finding of Cascio and Lewis (2006) that an exogenous increase in education leads to higher AFQT scores. Their finding would imply that decreased effort in school and in learning more broadly would result in a lower AFQT score. Regardless of interpretation, the impact of greater inequality on dropout behavior is substantial, albeit somewhat smaller if one accepts the interpretation that the AFQT measures innate ability.

\section{SELF-REPORTED REASONS FOR DROPPING OUT OF SCHOOL}

In an attempt to explore students’ own stated reasons for why they dropped out of school - and see if they are consistent with our proposed model- we take advantage of data from the High School and Beyond (HSB) survey. In 1980, high school sophomores were initially surveyed and then they were resurveyed in 1982. We focus on those in the 1982 survey who left school after their sophomore year interview in 1980. The sample for this "drop out survey" includes 2,421 individuals, or roughly 8 percent of the initial 1980 cohort. These individuals were asked why they dropped out and given a set of 16 possible reasons; they were allowed to and (3). This is another way to see that differences in AFQT capture about one-third of the estimated effect of inequality on the drop-out rates of low-SES boys. 
mark as many as applied. Though we acknowledge that students' self-reported reasons for dropping out of school might not accurately reflect underlying motivations, there is potentially something to be learned from whether the stated reasons were academic in nature.

A focus on perceptions - as discussed above - implies that the high school drop-out decision is less likely to be driven by academic difficulties. In other words, if a student perceives a lower benefit to remaining in school, then he will choose to drop out at a lower threshold of academic difficulty. We look to the data to see if there is any support for such a notion. The most direct measure of academic difficulty is "had poor grades/not doing well”. Other reasons that might reasonably be considered academic include the following: expelled or suspended; did not get into desired program; school grounds too dangerous and moved too far from school. The remaining 11 options include stated reasons that are less directly academic: had to support family, offered job and chose to work, school wasn't for me/didn’t like it, wanted to travel, wanted to enter military friends were dropping out, married or marriage plans, pregnant, illness/disability, couldn't get along with teachers, and couldn’t get along with students. Looking at the share of students who report each particular reason, and how this compares across states by inequality level, we see that 51 percent of dropouts in the least unequal states reported that they dropped out because of poor academic performance, as compared to only 21 percent of students who dropped out in the most unequal states. This is the only particular reason (of the 16) that shows a difference in shares across states by inequality level that is statistically significant.

Regression-adjusted results are similar. Controlling for the same set of individual- and state-level controls as described in equation (1) above, and controlling for a state fixed effect, the data indicate that low-SES students in the highest and middle range inequality states are 25-29 percentage points less likely to cite poor grades as a reason for dropping out. This represents a 
nearly 50 percent reduction in citing poor grades. This reason has by far the largest difference between low SES students in high and low inequality states. Although not conclusive, these survey data are broadly consistent with the notion that low-SES boys in more unequal states are more likely to drop out, not because they are struggling academically, but potentially because they perceive a lower return from staying in school. In other words, for the same level of academic performance, low-SES students in more unequal places are more likely to drop out of school.

\section{DISCUSSION}

In this paper we have proposed a mechanism through which greater levels of income inequality might lead to lower rates of upward mobility, namely, lower levels of high school completion among individuals from low-income backgrounds. We empirically test the proposition and test for the role of confounding factors and potential mechanisms. Our analysis offers compelling evidence that low-SES youth, boys in particular, are more likely to drop out of high school if they live in a place where the gap between the bottom and middle of the income distribution is wider.

The fact that boys appear to respond to greater levels of income inequality by dropping out of school more often is consistent with a growing body of evidence suggesting that boys suffer greater educational and labor market consequences from family and economic disadvantage (cf. Bertrand and Pan, 2013; Autor, Figlio, Karbownik, Roth, and Wasserman, 2015; and Chetty, et al., 2016). However, these patterns do not necessarily mean that low-SES girls are not affected by the economic disadvantage or conditions around them. They might simply respond on different margins. For instance, in Kearney and Levine (2014), we use 
empirical methods analogous to those we used in this paper and find that low-SES girls in more unequal places are significantly more likely to become young, unmarried mothers.

We interpret the findings as being consistent with - albeit not a conclusive demonstration of - a model of decision-making where a persistently wide gap between the bottom and middle of the income distribution has a negative effect on the perceived likelihood of economic success through human capital investments. This could occur either through impeded opportunity in actuality or through an effect on perceptions, shaped by a variety of factors experienced throughout one's childhood. The finding that higher levels of lower-tail income inequality leads to greater rates of drop out is robust to including the high school graduate wage premium in the regression model. In fact, the data indicate that the wage premium itself reduces the dropout rate, but household income inequality has an offsetting positive effect. In an additional set of models that examine potential mediating factors - including residential segregation and school financing - the data reject the hypotheses that any of the identified contextual factors are responsible for the relationship.

There are important policy implications of this work regarding the types of programs needed to improve the economic trajectory of children from low-SES backgrounds. Successful interventions would focus on ways for low socioeconomic youth to increase the likelihood of achieving economic success. Those interventions could focus on improving the actual return to investing in human capital for them, as we often discuss. But they also could focus on improving perceptions. College scholarship programs for low SES high school graduates, for instance, may make college a better investment for low-income youth and increase the return associated with graduation from high school. But it could also alter the student's perception that going to college is the sort of activity that they can achieve. They can be the "college-going type.” Other such 
interventions might take the form of mentoring programs that connect youth with successful adult mentors, school and community programs that focus on establishing high expectations and providing pathways to graduation. They could also take the form of early-childhood parenting programs that work with parents to create more nurturing home environments to build selfesteem and engender positive behaviors.

We believe these implications are consistent with the new set of results coming out of the Moving to Opportunity (MTO) experiment. MTO was a randomized control trial that offered housing vouchers and mobility counseling to inner-city, low-income families living in public housing. The results from the first generation of MTO movers provided little evidence that moving to a low-poverty neighborhood led to noticeable improvements in adult economic outcomes or teenager's educational attainment (Kling, Liebman, and Katz, 2007). But, more recent evidence from Chetty, Hendren, and Katz (2015) indicates that children who moved when they were very young experienced higher college attendance rates and ultimately received higher wages. The authors' interpretation of these findings is that the greater resources in the low poverty area had more time to take effect on the younger children. Although we do not dispute that interpretation, our model would additionally suggest that an important reason why the program was successful for younger children is because it changed their perceptions of what would be possible for them. Those children who moved at younger ages not only had the advantage of greater resources for a longer period of time, but they also spent less time with a highly disadvantaged peer group, which might have altered their perceptions of what was possible for them.

This interpretation also builds nicely on the contributions of Cunha, Heckman, Lochner, and Masterov (2006), and Cunha and Heckman (2007), among others, arguing that "skills beget 
skills.” The theory is that investments in skill at an early age compound and have a larger eventual effect on economic wellbeing than investments in skill at an older age. Our conceptualization might be complementary to that view, insofar as "perceptions beget perceptions.” This is not to say that later life interventions do not have the ability to improve one’s perceptions, but it may be more difficult to overcome that hurdle.

Our analysis has demonstrated that a greater persistent gap between the bottom of the income distribution and the middle leads to lower rates of high school completion among economically disadvantaged youth, boys in particular. These findings have implications for the potential of disadvantaged youth to achieve upward mobility and the types of policies that are likely to be successful. Furthermore, they reflect a plausible channel through which higher rates of income inequality might causally lead to lower rates of social mobility. To improve rates of upward mobility, we need to give economically disadvantaged youth reasons to believe that they can achieve economic success. 


\section{REFERENCES}

Akerlof, George A. and Rachel E. Kranton (2000). “Economics and Identity.” Quarterly Journal of Economics, 115(3): 715-753.

Autor, David, David Figlio, Krzysztof Karbownik, Jeffrey Roth, and Melanie Wasserman (2015). "Family Disadvantage and the Gender Gap in Behavioral and Educational Outcomes," IPR Northwestern working paper 15-16, October.

Becker, Gary S. and Kevin M. Murphy (2007). “The Upside of Income Inequality.” The American. May/June.

Becker, Gary S., and Nigel Tomes (1979). “An Equilibrium Theory of the Distribution of Income and Intergenerational Mobility.” Journal of Political Economy. Vol. 87, pp. 1153-89.

Bertrand, Marianne and Jessica Pan, “The Trouble with Boys: Social Influences and the Gender Gap in Disruptive Behavior,” American Economic Journal: Applied Economics, January 2013, 5(1), 32-64.

Belley, Philippe, and Lance Lochner (2007). "The Changing Role of Family Income and Ability in Determining Educational Achievement," Journal of Human Capital, 1(1): 37-89.

Boustan, Leah, Fernando Ferreira, Hernan Winkler, and Eric Zolt (2013). “The Effect of Rising Income Inequality on Taxation and Public Expenditures: Evidence from US Municipalities and School Districts, 1970-2000.” Review of Economics and Statistics, 95(4): 1291-1302.

Cascio, Elizabeth U. and Ethan G. Lewis (2006). "Schooling and the Armed Forces Qualifying Test Evidence from School-Entry Laws.” Journal of Human Resources, 41(2): 294-318.

Case, Anne C. and Lawrence F. Katz (1991). "The Company You Keep: The Effects of Family and Neighborhood on Disadvantaged Youths," NBER Working Paper No. 3705.

Center on Education Policy (2010). State High School Tests: Exit Exams and Other Assessments. Washington, DC: Center on Education Policy.

Chetty, Raj and Nathaniel Hendren (2015). "The Impacts of Neighborhoods on Intergenerational Mobility: Childhood Exposure Effects and County-Level Estimates”, Harvard University mimeo, May.

Chetty, Raj, Nathaniel Hendren, and Lawrence F. Katz (2015). “The Effects of Exposure to Better Neighborhoods on Children: New Evidence from the Moving to Opportunity Experiment” NBER Working Paper No. 21156, May. 
Chetty, Raj, Nathaniel Hendren, Patrick Kline, and Emmanuel Saez (2014a). "Where is the Land of Opportunity? The Geography of Intergenerational Mobility in the United States.” Quarterly Journal of Economics 129(4): 1553-1623.

Chetty, Raj, Nathaniel Hendren, Patrick Kline, and Emmanuel Saez (2014b). "Is the United States Still a Land of Opportunity? Recent Trends in Intergenerational Mobility.” NBER Working Paper 19844.

Chetty, Raj, Nathaniel Hendren, Frina Lin, Jeremy Majerovitz, Benjamin Scuderi (2016). “Childhood Environment and Gender Gaps in Adulthood.” NBER Working Paper 21936.

Corak, Miles (2006). "Do Poor Children Become Poor Adults? Lessons from a Cross-Country Comparison of Generational Earnings Mobility.” Research on Economic Inequality, 13: 143188.

Corak, Miles (2013). "Income Inequality, Equality of Opportunity, and Intergenerational Mobility." Journal of Economic Perspectives, 27(3): 79-102.

Corcoran, Sean and William N. Evans (2010). "Income Inequality, the Median Voter, and the Support for Public Education.” Cambridge, MA: NBER working paper 16097.

Council of Economic Advisers (2012). Economic Report of the President. Washington, DC: Government Printing Office.

Cunha, Flavio, James J. Heckman, Lance Lochner, Dimitriy V. Masterov (2006). "Interpreting the Evidence on Life Cycle Skill Formation," in Eric Hanuschek and Finis Welch, Handbook of the Economics of Education, Amsterdam: North-Holland.

Cunha, Flávio, and James J. Heckman (2007), “The Technology of Skill Formation,” American Economic Review 97(2): 31-47.

Dee, Thomas S. and Jacob, Brian A. (2007). "Do High School Exit Exams Influence Educational Attainment or Labor Market Performance?” In Adam Gamoran (ed.), StandardsBased Reform and the Poverty Gap: Lessons for No Child Left Behind. Washington, D.C.: Brookings University Press.

Destin, Mesmin, Scott Richman, Fatima Varner, and Jelani Mandara. (2012). "Feeling" hierarchy: The pathway from subjective social status to achievement." Journal of Adolescence 35, 1571-1579.

Duncan, Greg J., and Richard J. Murnane (2011). "Introduction: The American Dream, Then and Now,” In Greg J. Duncan and Richard J. Murnane (eds.), Whither Opportunity? Rising Inequality, Schools, and Children's Life Chances. New York: Russell Sage Foundation. 
Genicot, Garance, and Debraj Ray (2014). “Aspirations and Inequality.” Cambridge, MA: National Bureau of Economic Research working paper 19976.

Goldin, Claudia and Larry F. Katz. The Race between Education and Technology. Cambridge, Harvard University Press. 2010.

Gordon, Nora (2013). "High School Graduation in the Context of Changing Elementary and Secondary Education Policy and Income Inequality: The Last Half Century,” National Bureau of Economic Research working paper 19049.

Grogger, Jeffrey T. (1996). "School Expenditures and Post-Schooling Earnings: Evidence from High School and Beyond." Review of Economics and Statistics 78(4): 628-637.

Heckman, James J. and Paul A. LaFontaine (2010). "The American High School Graduation Rate: Trends and Levels,” Review of Economics and Statistics 92 (2): 244-262.

Herrnstein, Richard and Charles Murray (1994). The Bell Curve: Intelligence and Class Structure in American Life. New York: Simon and Schuster.

Ikoma, Sakiko, and Markus Broer (2015). "How Can We Help Students Match College Aspirations to College Enrollment?” available at: http://educationpolicy.air.org/blog/how-canwe-help-students-match-college-aspirations-college-enrollment (accessed 2/15/2016).

Jensen, Robert (2010). “The (Perceived) Returns to Education and the Demand for Schooling," Quarterly Journal of Economics, 125(2): 515-548.

Kearney, Melissa S. and Phillip B. Levine (2012). "Investigating Recent Trends in the U.S. Teen Birth Rate,” National Bureau of Economic Research working paper 17964.

Kearney, Melissa and Phillip Levine (2014). "Income Inequality and Early Non-Marital Childbearing,” Journal of Human Resources, 49(1): pp. 1-31.

Kling, Jeffrey R., Jeffrey B. Liebman, and Lawrence F. Katz (2007). “Experimental Analysis of Neighborhood Effects.” Econometrica 75(1): 83-119.

Kling, Jeffrey R., Jens Ludwig, and Lawrence F. Katz (2005). "Neighborhood Effects on Crime for Female and Male Youth: Evidence from a Randomized Housing Voucher Experiment.” Quarterly Journal of Economics. 120(1):87-130.

Lee, Chul-In and Gary Solon. (2009). “Trends in Intergenerational Income Mobility,” Review of Economics and Statistics 91(4), 766-772.

Luttmer, Erzo. F. P. (2005). "Neighbors as Negatives: Relative Earnings and Well-Being." Quarterly Journal of Economics 120(3): 963-1002. 
Mankiw, N Gregory (2013). "Defending the One Percent." Journal of Economic Perspectives, 27(3): 21-34.

Manski, Charles F. (1993). “Adolescent Econometricians: How Do Youth Infer the Returns to Education?” in Charles T. Clotfelter and Michael Rothschild (eds.), Studies of Supply and Demand in Higher Education. Chicago: University of Chicago Press.

Mayer, Susan (2001). "How did the Increase in Economic Inequality between 1970 and 1990 Affect Children’s Educational Attainment.” American Journal of Sociology, 107(1):1-32.

Neal, Derek and William R. Johnson (1996). "The Role of Premarket Factors in Black-White Wage Differences.” Journal of Political Economy 104(5): 869-895.

Putnam, Robert D. (2000). Bowling Alone. New York: Simon \& Schuster.

Reardon, Sean F. (2011). "Measures of Income Segregation." CEPA Working Papers. Stanford, CA: Stanford Center for Education Policy Analysis.

Ruggles, Steven J., Trent Alexander, Katie Genadek, Ronald Goeken, Matthew B. Schroeder, and Matthew Sobek. (2010) Integrated Public Use Microdata Series: Version 5.0 [Machinereadable database]. Minneapolis: University of Minnesota.

Rumberger, Russell W. (2011). Dropping Out : Why Students Drop Out of High School and what can be done about it. Cambridge, Mass.: Harvard University Press.

Sawhill, Isabel V. (2014). Generations Unbound: Drifting into Sex and Parenting without Marriage. Washington, DC: Brookings Institution.

Solon, Gary (2004). “A model of intergenerational mobility variation over time and place,” in ed. Miles Corak, Generational Income Mobility in Europe and North America, Cambridge University Press: 2004: 38-47.

Stetser, Marie C. and Robert Stillwell (2014). Public High School Four-Year On-Time Graduation Rates and Event Dropout Rates: School Years 2010-11 and 2011-12. First Look (NCES 2014-391). U.S. Department of Education. Washington, DC: National Center for Education Statistics. Retrieved 12/1/15 from http://nces.ed.gov/pubsearch.

Watson, Tara (2009). “Inequality and the Measurement of Residential Segregation by Income.” Review of Income and Wealth, 55: 820-844.

Watson, Tara, and Sara McLanahan (2011). "Marriage Meets the Joneses: Relative Income, Identity, and Marital Status.” Journal of Human Resources, 46: 568-586.

Wilkinson, Richard and Kate Pickett (2009). The Spirit Level: Why Greater Equality Makes Societies Stronger. London: Bloomsbury Press. 
Wilson, William J (1987). The Truly Disadvantaged: The Inner City, the Underclass and Public Policy. Chicago: University of Chicago Press.

Winship, Scott (2015). “The Great Gatsby Curve: All Heat, No Light.” Available at: http://www.brookings.edu/blogs/social-mobility-memos/posts/2015/05/20-opposition-greatgatsby-curve-winship (accessed 12/1/15). 
Table 1: Impact of Long-Term Inequality by State

on Educational Attainment by Age 20, by Socioeconomic Status and Gender

High School Dropout

(1)
GED Receipt

(2)

All

\begin{tabular}{lccc} 
& & All & \\
Percent in Category & 10.1 & 4.8 & 85.1 \\
\hline 50/10 Ratio* & 0.023 & -0.006 & -0.017 \\
$\quad$ Mom HS Dropout & $(0.015)$ & $(0.010)$ & $(0.016)$ \\
& & & -0.028 \\
50/10 Ratio* & 0.018 & 0.010 & $(0.013)$ \\
$\quad$ Mom HS Graduate & $(0.014)$ & $(0.008)$ & \\
\hline & & Boys & 83.3 \\
\hline Percent in Category & & & -0.022 \\
\hline 50/10 Ratio* & 11.2 & 5.5 & $(0.018)$ \\
Mom HS Dropout & 0.041 & -0.018 & -0.037 \\
50/10 Ratio* & $(0.015)$ & $(0.015)$ & $(0.016)$ \\
Mom HS Graduate & & & \\
\hline
\end{tabular}

Girls

\begin{tabular}{lccc} 
Percent in Category & 9.1 & 4.1 & 86.8 \\
\hline 50/10 Ratio* & 0.007 & 0.005 & -0.012 \\
$\quad$ Mom HS Dropout & $(0.019)$ & $(0.010)$ & $(0.022)$ \\
& & & -0.015 \\
50/10 Ratio* & 0.009 & 0.006 & $(0.016)$ \\
$\quad$ Mom HS Graduate & $(0.014)$ & $(0.011)$ & \\
\hline
\end{tabular}

Notes: Reported standard errors (in parenthesis) are adjusted for clustering at the state level. Additional explanatory variables in each regression include maternal educational attainment, gender (where appropriate) race/ethnicity, an indicator variable for living with a single parent at age 14, the state unemployment rate at age 16, the state minimum wage, state education policies (compulsory schooling age and indicators for high school exit exam requirements), state welfare policies (family cap and maximum AFDC/TANF benefit for a family of 3), state abortion policies (Medicaid funding, parental notification/consent, and mandatory delay laws), and indicator variables for SCHIP implementation and a Medicaid family planning waiver program, along with state and cohort fixed effects. The pvalue of a test comparing the equality of coefficients in column (1) by gender in response to a change in the 50/10 ratio*mom HS dropout is 0.086. Sample includes data from the NELS, HSB, ELS, NLSY79, and NLSY97. The total sample size is 53,150, with 25,816 boys and 27,334 girls. 
Table 2: Impact of Long-Term Inequality by MSA On Likelihood of Dropping Out of High School, by Socioeconomic Status and Gender

\begin{tabular}{|c|c|c|c|}
\hline & $\begin{array}{l}\text { All } \\
(1)\end{array}$ & $\begin{array}{l}\text { Boys } \\
(2)\end{array}$ & $\begin{array}{c}\text { Girls } \\
(3)\end{array}$ \\
\hline$\underline{\text { Percent in Category }}$ & 12.3 & 14.1 & 10.6 \\
\hline $\begin{array}{l}\text { 50/10 Ratio* } \\
\text { Mom HS Dropout }\end{array}$ & $\begin{array}{c}0.036 \\
(0.013)\end{array}$ & $\begin{array}{c}0.073 \\
(0.018)\end{array}$ & $\begin{array}{c}0.002 \\
(0.016)\end{array}$ \\
\hline $\begin{array}{l}\text { 50/10 Ratio* } \\
\text { Mom HS Graduate }\end{array}$ & $\begin{array}{c}0.020 \\
(0.011)\end{array}$ & $\begin{array}{c}0.028 \\
(0.016)\end{array}$ & $\begin{array}{c}0.009 \\
(0.012)\end{array}$ \\
\hline Sample size & 22,304 & 11,042 & 11,262 \\
\hline
\end{tabular}


Table 3: Impact of Alternative Income Distribution Measures on Boys' Likelihood of Dropping Out of High School, by Socioeconomic Status

\begin{tabular}{|c|c|c|c|c|c|}
\hline & $\begin{array}{l}50 / 10 \text { ratio } \\
\text { (1) }\end{array}$ & $\begin{array}{c}90 / 50 \text { ratio } \\
(2)\end{array}$ & $\begin{array}{c}10^{\text {th }} \text { Percentile } \\
\text { of Income } \\
\text { (in } \$ 10,000 \mathrm{~s} \text { ) } \\
(3)\end{array}$ & $\begin{array}{c}50^{\text {th }} \text { Percentile } \\
\text { of Income } \\
\text { (in } \$ 10,000 \mathrm{~s} \text { ) } \\
(4)\end{array}$ & $\begin{array}{c}\text { Income Share } \\
\text { top } 1 \% \\
\text { (5) }\end{array}$ \\
\hline $\begin{array}{l}\text { Correlation between 50/10 ratio } \\
\text { and characteristic: }\end{array}$ & & 0.67 & -0.63 & -0.20 & 0.38 \\
\hline $\begin{array}{l}\text { 50/10 Ratio* } \\
\text { Mom HS Dropout }\end{array}$ & $\begin{array}{c}0.041 \\
(0.015)\end{array}$ & $\begin{array}{c}0.058 \\
(0.025)\end{array}$ & $\begin{array}{c}0.041 \\
(0.024)\end{array}$ & $\begin{array}{c}0.041 \\
(0.016)\end{array}$ & $\begin{array}{c}0.042 \\
(0.018)\end{array}$ \\
\hline $\begin{array}{l}\text { 50/10 Ratio* } \\
\text { Mom HS Graduate }\end{array}$ & $\begin{array}{c}0.025 \\
(0.017)\end{array}$ & $\begin{array}{c}0.023 \\
(0.019)\end{array}$ & $\begin{array}{c}0.024 \\
(0.021)\end{array}$ & $\begin{array}{c}0.024 \\
(0.017)\end{array}$ & $\begin{array}{c}0.029 \\
(0.017)\end{array}$ \\
\hline $\begin{array}{l}\text { State Characteristic* } \\
\text { Mom HS Dropout }\end{array}$ & --- & $\begin{array}{l}-0.069 \\
(0.072)\end{array}$ & $\begin{array}{l}0.0002 \\
(0.005)\end{array}$ & $\begin{array}{l}-0.0001 \\
(0.001)\end{array}$ & $\begin{array}{l}-0.001 \\
(0.003)\end{array}$ \\
\hline $\begin{array}{l}\text { State Characteristic* } \\
\text { Mom HS Graduate }\end{array}$ & --- & $\begin{array}{c}0.004 \\
(0.050)\end{array}$ & $\begin{array}{r}-0.0001 \\
(0.003)\end{array}$ & $\begin{array}{r}-0.0003 \\
(0.001)\end{array}$ & $\begin{array}{l}-0.001 \\
(0.002)\end{array}$ \\
\hline
\end{tabular}

Notes: see notes to Table 1. Interacted state characteristic is listed in column headers. 
Table 4: Impact of Educational Wage Premiums on Boys’ Likelihood of Dropping Out of High School, by Socioeconomic Status

\begin{tabular}{|c|c|c|c|}
\hline & $\begin{array}{c}50 / 10 \text { ratio } \\
(1)\end{array}$ & $\begin{array}{c}\text { HS Grad to } \\
\text { HS Dropout } \\
\text { Wage Premium } \\
(2) \\
\end{array}$ & $\begin{array}{l}\text { College Grad to } \\
\text { HS Grad } \\
\text { Wage Premium } \\
\text { (3) }\end{array}$ \\
\hline $\begin{array}{l}\text { Correlation between 50/10 ratio } \\
\text { and characteristic: }\end{array}$ & & 0.27 & 0.35 \\
\hline $\begin{array}{l}\text { 50/10 Ratio* } \\
\text { Mom HS Dropout }\end{array}$ & $\begin{array}{c}0.041 \\
(0.015)\end{array}$ & $\begin{array}{c}0.046 \\
(0.015)\end{array}$ & $\begin{array}{c}0.037 \\
(0.017)\end{array}$ \\
\hline $\begin{array}{l}\text { 50/10 Ratio* } \\
\text { Mom HS Graduate }\end{array}$ & $\begin{array}{c}0.025 \\
(0.017)\end{array}$ & $\begin{array}{c}0.023 \\
(0.018)\end{array}$ & $\begin{array}{c}0.022 \\
(0.019)\end{array}$ \\
\hline $\begin{array}{l}\text { State Characteristic* } \\
\text { Mom HS Dropout }\end{array}$ & --- & $\begin{array}{l}-0.117 \\
(0.076)\end{array}$ & $\begin{array}{c}0.039 \\
(0.043)\end{array}$ \\
\hline $\begin{array}{l}\text { State Characteristic* } \\
\text { Mom HS Graduate }\end{array}$ & $\begin{array}{l}--- \\
---\end{array}$ & $\begin{array}{c}0.029 \\
(0.062)\end{array}$ & $\begin{array}{c}0.024 \\
(0.043)\end{array}$ \\
\hline
\end{tabular}

Notes: see notes to Table 1. Interacted state characteristic is listed in column headers. 
Table 5: Impact of Measures of Segregation on Boys' Likelihood of Dropping Out of High School, by Socioeconomic Status

\begin{tabular}{lcccc}
\hline & $\begin{array}{c}\text { Racial } \\
\text { ratio } \\
(1)\end{array}$ & $\begin{array}{c}\text { Segregation } \\
\text { Index } \\
(2)\end{array}$ & $\begin{array}{c}\text { Income } \\
\text { Segregation } \\
\text { Index } \\
(3)\end{array}$ & $\begin{array}{c}\text { Poverty } \\
\text { Segregation } \\
\text { Index } \\
(4)\end{array}$ \\
\hline $\begin{array}{l}\text { Correlation between 50/10 } \\
\text { ratio and characteristic: }\end{array}$ & & 0.05 & 0.47 & 0.26 \\
\hline 50/10 Ratio* & 0.041 & 0.040 & 0.040 & 0.037 \\
$\quad$ Mom HS Dropout & $(0.015)$ & $(0.017)$ & $(0.016)$ & $(0.017)$ \\
50/10 Ratio* & 0.025 & 0.025 & 0.025 & 0.024 \\
$\quad$ Mom HS Graduate & $(0.017)$ & $(0.015)$ & $(0.017)$ & $(0.017)$ \\
State Characteristic* & --- & 0.0008 & 0.050 & 0.281 \\
$\quad$ Mom HS Dropout & -- & $(0.0008)$ & $(0.396)$ & $(0.496)$ \\
State Characteristic* & --- & -0.0008 & 0.0001 & 0.050 \\
$\quad$ Mom HS Graduate & -- & $(0.0004)$ & $(0.204)$ & $(0.260)$ \\
\hline \hline
\end{tabular}

Notes: see notes to Table 1. Interacted state characteristic is listed in column headers. 
Table 6: Impact of Potential Mediating Factors on Boys' Likelihood of Dropping Out of High School, by Socioeconomic Status

\begin{tabular}{|c|c|c|c|c|c|}
\hline & $\begin{array}{l}50 / 10 \text { ratio } \\
\text { (1) }\end{array}$ & $\begin{array}{c}\text { Per Capita } \\
\text { Educational } \\
\text { Expenditures } \\
(/ 1,000) \\
(2)\end{array}$ & $\begin{array}{c}\text { Pupil } \\
\text { Teacher Ratio } \\
\text { (/10) } \\
\text { (3) }\end{array}$ & $\begin{array}{c}\text { Social } \\
\text { Capital Index } \\
\text { (4) }\end{array}$ & $\begin{array}{c}\text { Fraction } \\
\text { Single Parent } \\
\text { (5) }\end{array}$ \\
\hline $\begin{array}{l}\text { Correlation between 50/10 } \\
\text { ratio and characteristic: }\end{array}$ & & 0.17 & -0.24 & -0.44 & 0.64 \\
\hline $\begin{array}{l}\text { 50/10 Ratio* } \\
\text { Mom HS Dropout }\end{array}$ & $\begin{array}{c}0.041 \\
(0.015)\end{array}$ & $\begin{array}{c}0.036 \\
(0.015)\end{array}$ & $\begin{array}{c}0.029 \\
(0.015)\end{array}$ & $\begin{array}{c}0.045 \\
(0.019)\end{array}$ & $\begin{array}{c}0.036 \\
(0.019)\end{array}$ \\
\hline $\begin{array}{l}\text { 50/10 Ratio* } \\
\text { Mom HS Graduate }\end{array}$ & $\begin{array}{c}0.025 \\
(0.017)\end{array}$ & $\begin{array}{c}0.019 \\
(0.012)\end{array}$ & $\begin{array}{c}0.020 \\
(0.015)\end{array}$ & $\begin{array}{c}0.016 \\
(0.019)\end{array}$ & $\begin{array}{c}0.015 \\
(0.022)\end{array}$ \\
\hline $\begin{array}{l}\text { State Characteristic* } \\
\text { Mom HS Dropout }\end{array}$ & --- & $\begin{array}{l}-0.001 \\
(0.003)\end{array}$ & $\begin{array}{l}-0.003 \\
(0.002)\end{array}$ & $\begin{array}{c}0.008 \\
(0.008)\end{array}$ & $\begin{array}{c}0.092 \\
(0.247)\end{array}$ \\
\hline $\begin{array}{l}\text { State Characteristic* } \\
\text { Mom HS Graduate }\end{array}$ & --- & $\begin{array}{l}-0.005 \\
(0.002)\end{array}$ & $\begin{array}{c}0.004 \\
(0.002)\end{array}$ & $\begin{array}{l}-0.007 \\
(0.005)\end{array}$ & $\begin{array}{c}0.192 \\
(0.221)\end{array}$ \\
\hline
\end{tabular}

Notes: see notes to Table 1. Interacted state characteristic is listed in column headers. 
Table 7: Impact of Potentially Confounding State Characteristics on Boys' Likelihood of Dropping Out of High School, by Socioeconomic Status

\begin{tabular}{lccccc}
\hline \hline & & Percent & Poverty \\
Rate & $\begin{array}{c}\text { Minority } \\
(2)\end{array}$ & $\begin{array}{c}\text { Incarceration } \\
\text { Rate }(/ 1,000) \\
(4)\end{array}$ & $\begin{array}{c}\text { Fraction } \\
\text { Employed in } \\
\text { Manufacturing } \\
(5)\end{array}$ \\
\hline $\begin{array}{l}\text { Correlation between 50/10 ratio } \\
\text { and characteristic: }\end{array}$ & & 0.41 & 0.63 & 0.44 & -0.10 \\
\hline 50/10 Ratio* & 0.041 & 0.053 & 0.056 & 0.043 & 0.043 \\
$\quad$ Mom HS Dropout & $(0.017)$ & $(0.018)$ & $(0.026)$ & $(0.021)$ & $(0.015)$ \\
$\begin{array}{l}\text { 50/10 Ratio* } \\
\quad \text { Mom HS Graduate }\end{array}$ & 0.024 & 0.021 & 0.021 & 0.008 & 0.024 \\
$\begin{array}{l}\text { State Characteristic* } \\
\text { Mom HS Dropout }\end{array}$ & $(0.012)$ & $(0.017)$ & $(0.021)$ & $(0.014)$ & $(0.017)$ \\
State Characteristic* & --- & -0.0007 & -0.003 & -0.047 & 0.221 \\
$\quad$ Mom HS Graduate & -- & $(0.0004)$ & $(0.004)$ & $(0.092)$ & $(0.148)$ \\
\hline \hline
\end{tabular}

Notes: See notes to Table 1. Interacted state characteristic is listed in column headers. 
Table 8: Relationship between Socioeconomic Status, Inequality, and AFQT Scores for Boys

\begin{tabular}{|c|c|c|c|c|}
\hline Sample & $\begin{array}{c}\text { All } 5 \text { Datasets } \\
(1)\end{array}$ & $\begin{array}{l}\text { NLSY79 and } \\
\text { NLSY97 } \\
(2)\end{array}$ & $\begin{array}{l}\text { NLSY79 and } \\
\text { NLSY97 } \\
(3)\end{array}$ & $\begin{array}{l}\text { NLSY79 and } \\
\text { NLSY97 } \\
(4)\end{array}$ \\
\hline Dependent Variable & HS Dropout & HS Dropout & HS Dropout & AFQT \\
\hline Mean of Dependent Variable & 11.2 & 17.7 & 17.7 & 50.7 \\
\hline Mom HS Dropout*50/10 Ratio & $\begin{array}{c}0.042 \\
(0.016)\end{array}$ & $\begin{array}{c}0.067 \\
(0.029)\end{array}$ & $\begin{array}{c}0.045 \\
(0.028)\end{array}$ & $\begin{array}{l}-4.48 \\
(2.49)\end{array}$ \\
\hline Mom HS Graduate*50/10 Ratio & $\begin{array}{c}0.024 \\
(0.018)\end{array}$ & $\begin{array}{c}0.077 \\
(0.025)\end{array}$ & $\begin{array}{c}0.057 \\
(0.023)\end{array}$ & $\begin{array}{l}-4.10 \\
(2.27)\end{array}$ \\
\hline AFQT & --- & --- & $\begin{array}{c}-0.005 \\
(0.0002)\end{array}$ & \\
\hline
\end{tabular}

Notes: Reported standard errors in parenthesis are adjusted for clustering at the state level. Estimates in Column 1 differ slightly from previous estimates because no state level policy variables are included. The sample used in Column 2 is restricted to those observations with available AFQT scores to compare to Column 3. The samples used for the regressions in Columns 2 through 4 are the NLSY79 and NLSY97 and the sample size is 7,955. 


\section{Figure 1: Great Gatsby Curve in the United States}

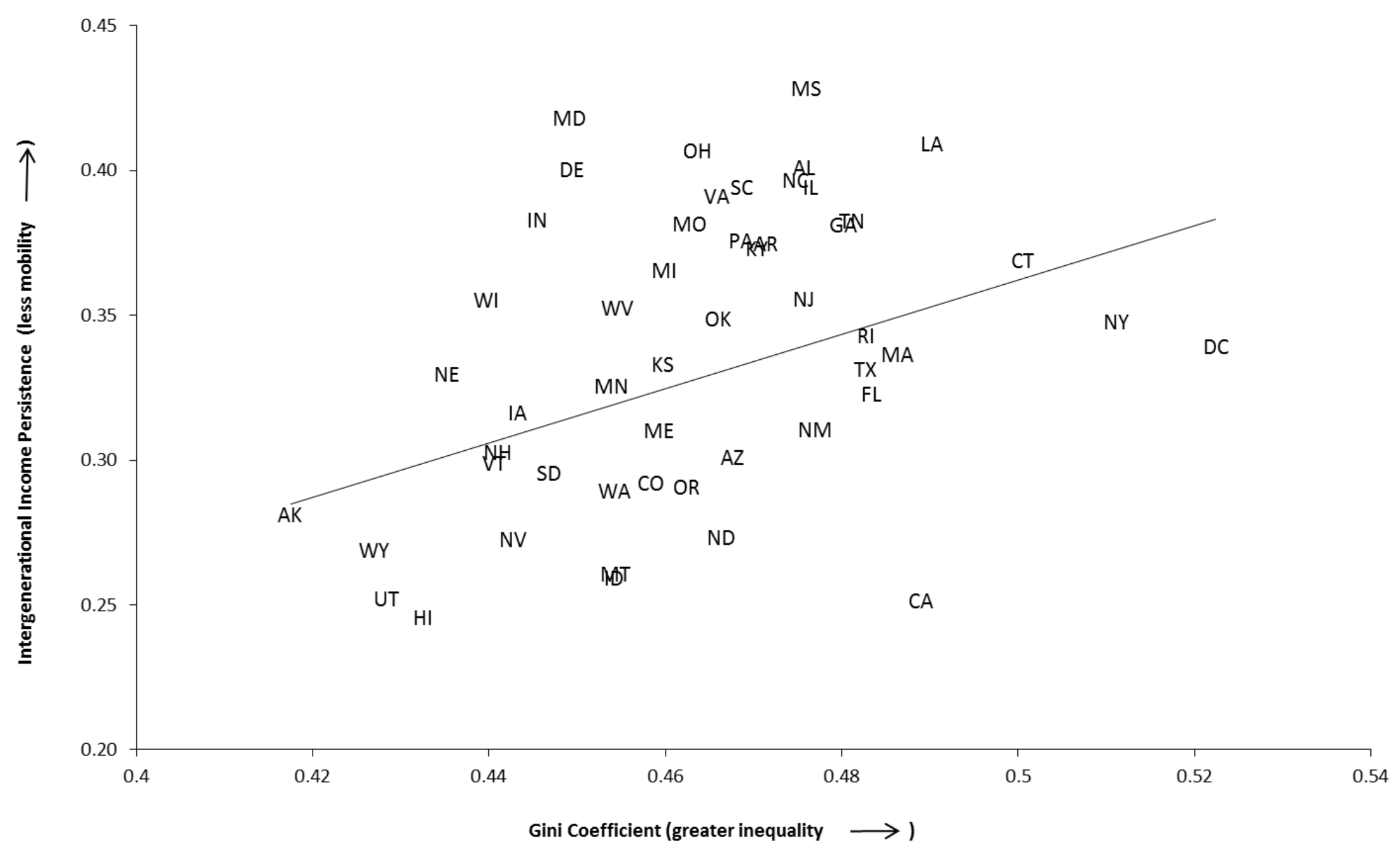

Notes: Income persistence is the relative mobility measure obtained from Chetty, et al. (2014). The Gini Coefficient data come from the U.S. Bureau of the Census, 2014 American Community Survey. 


\section{Figure 2: Trends in Mobility and Inequality in the United States}

0.60

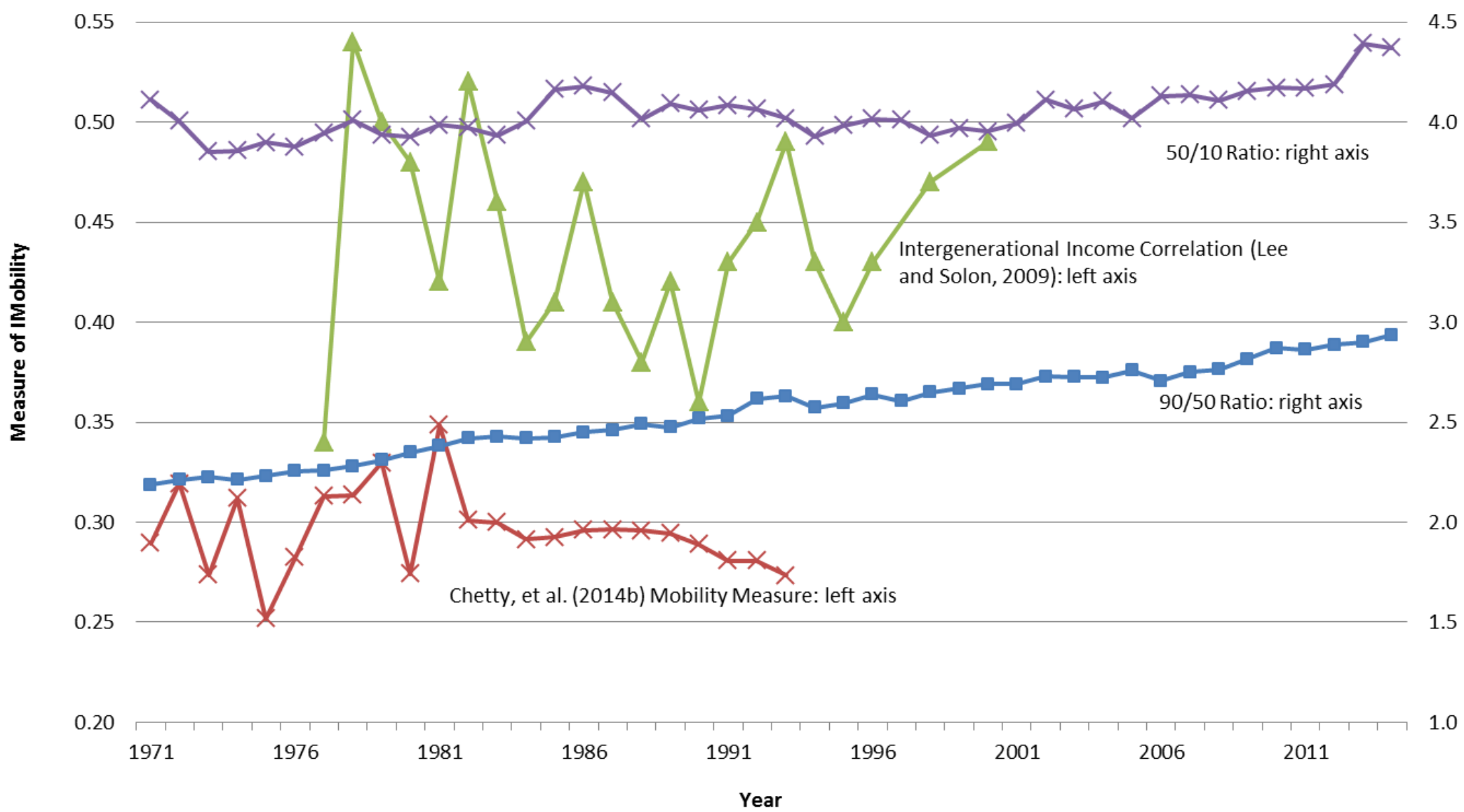

notes: The $x$-axis reflects the year in which income is measured for the 90/50 and 50/10 ratios. For the mobility measure in Chetty, et al. (2014b), year reflects birth cohort. For the mobility measure in Lee and Solon (2009), year reflects the year in which the son's income was recorded. 


\section{Figure 3: Relationship between Inequality and the Rate of High School Non-Completion}

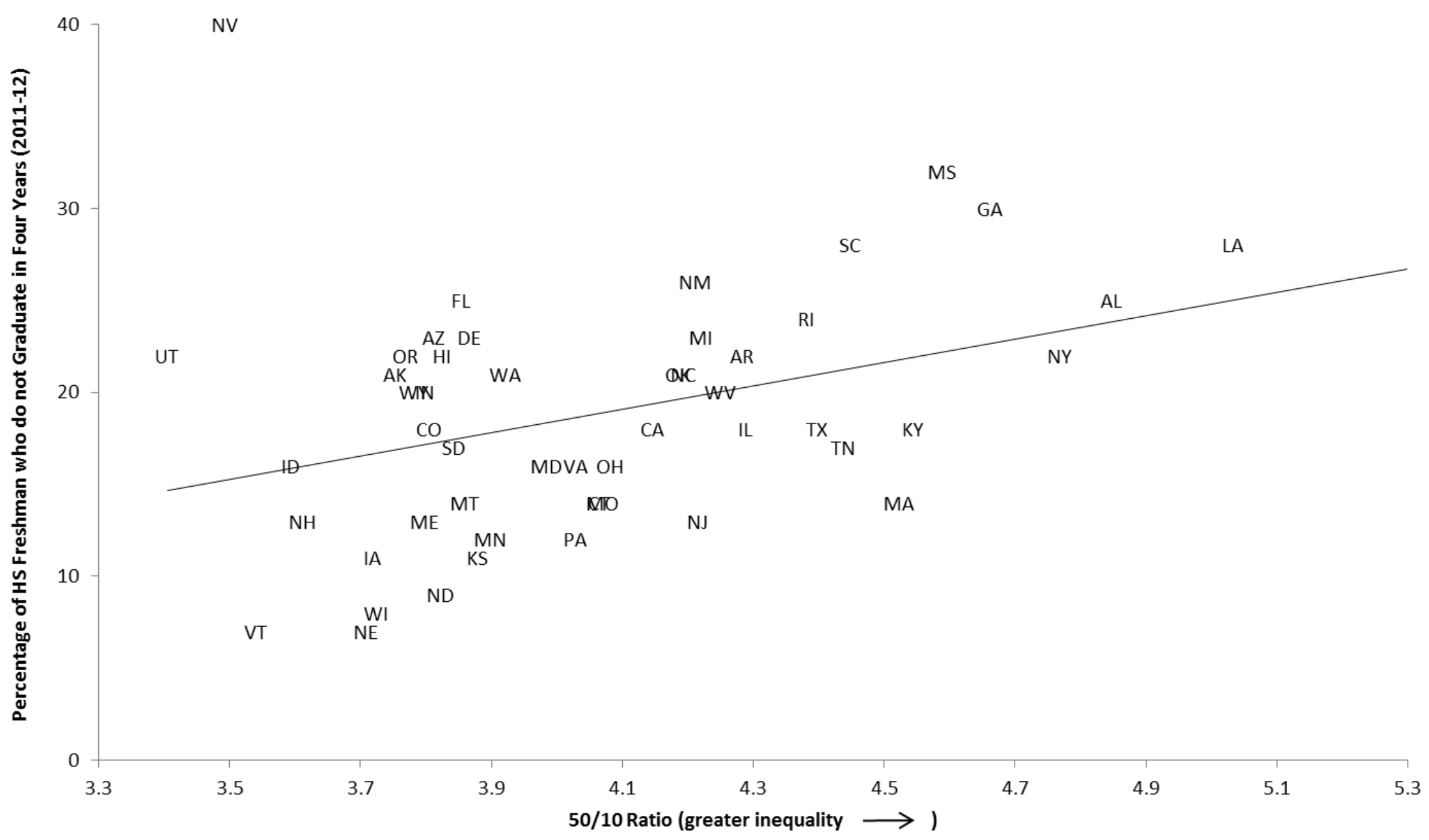

Notes: The graduation data is from Stetser and Stillwell (2014). The 50/10 ratios are calculated by the authors. The District of Columbia is omitted from this figure because it is an extreme outlier on the $X$ axis $(50 / 10$ ratio $=5.66)$. 
Figure 4: Rate of Return to Education by Mother's Level of Education and State Level of Income Inequality (50/10 Ratio)

Percent

14

12

Least

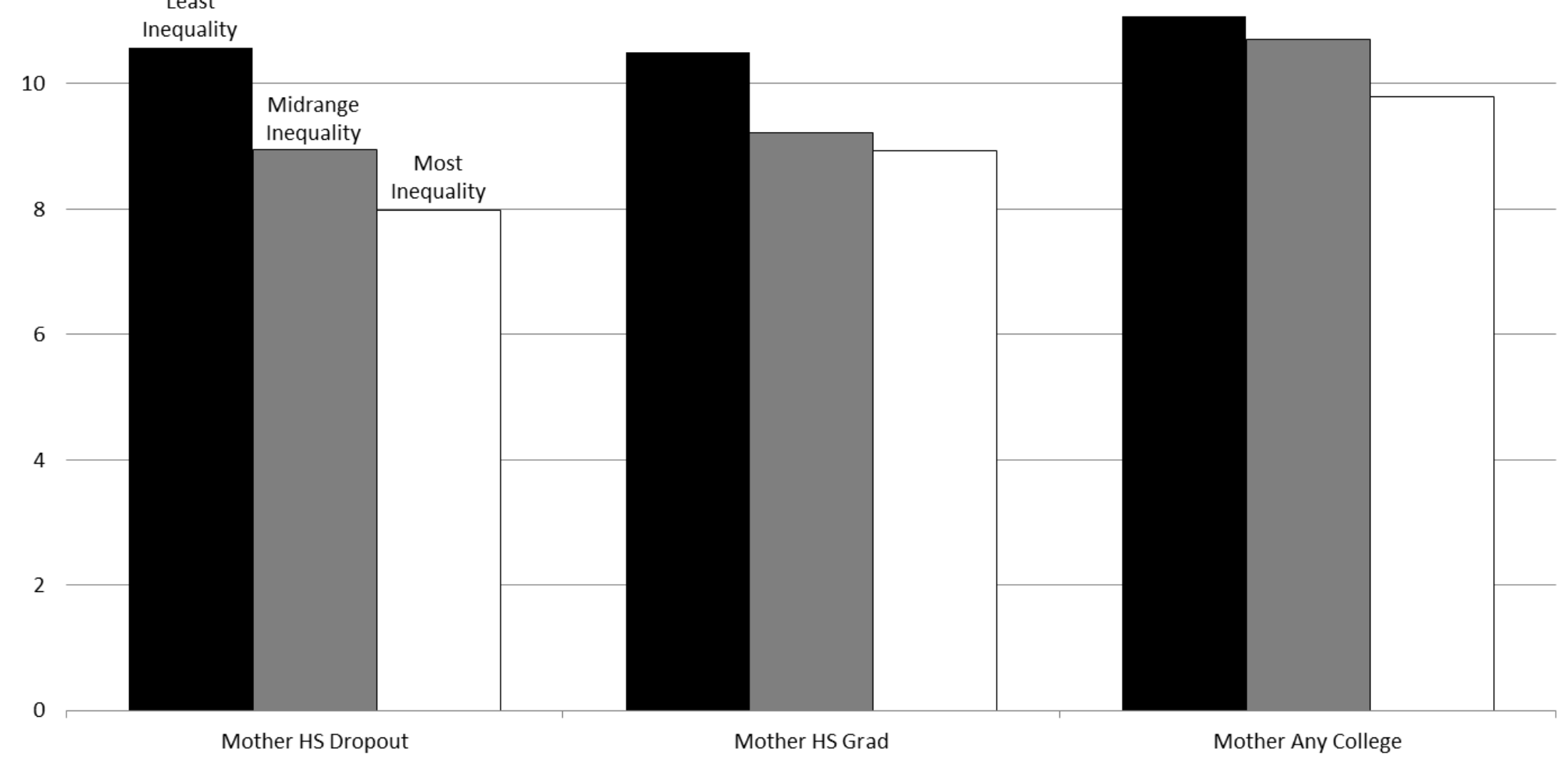

Mother HS Dropout

Mother HS Grad

Mother Any College 
Figure 5: High School Dropout Rate for Boys by Mother's Level of Education and State Level of Income Inequality (50/10 Ratio)

Percent

30

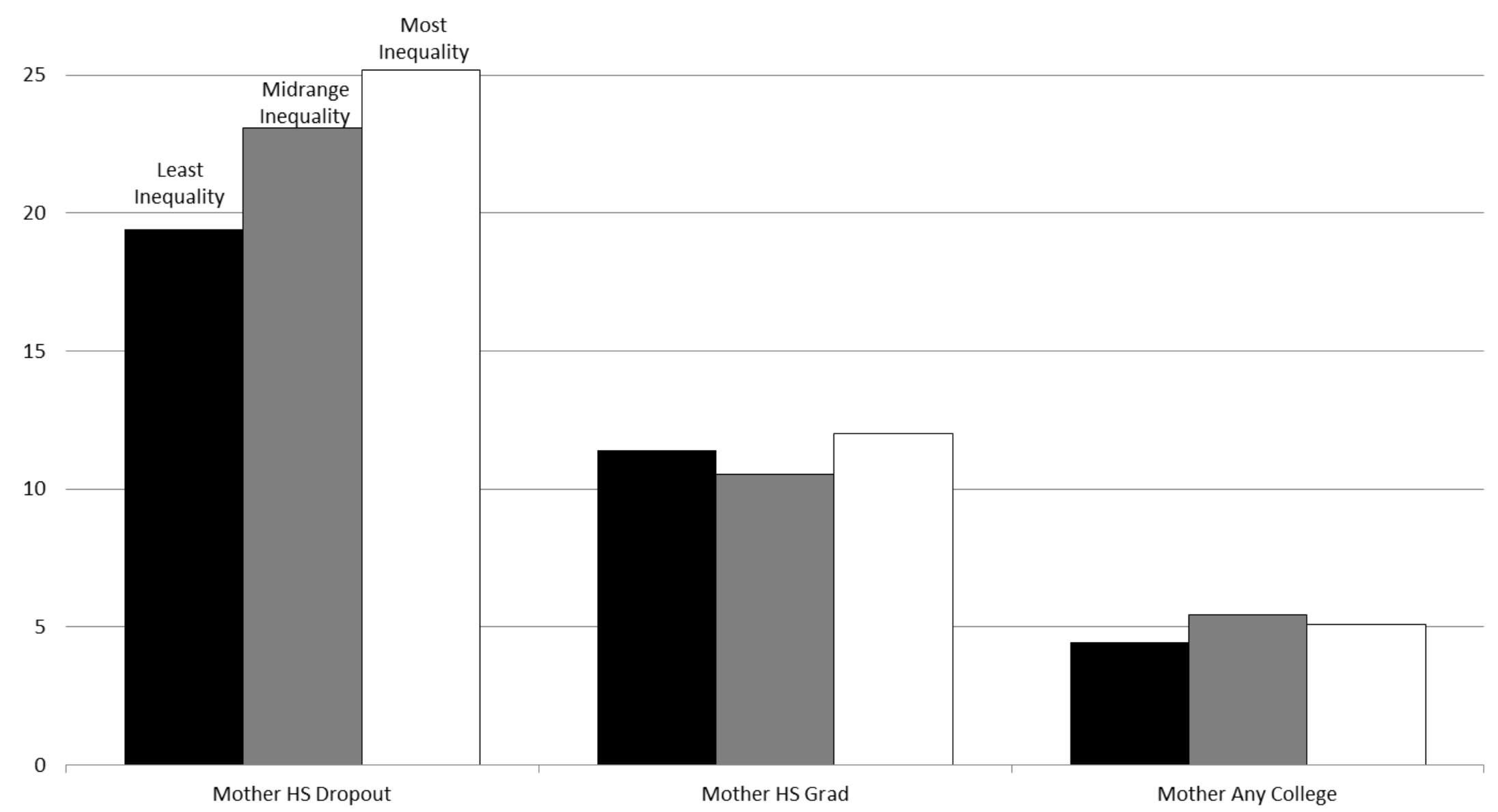


Appendix Table 1: Impact of Alternative Income Distribution Measures on Boys' Likelihood of Dropping Out of High School, by Socioeconomic Status (MSA Level)

\begin{tabular}{|c|c|c|c|c|c|}
\hline & $\begin{array}{l}50 / 10 \text { ratio } \\
\text { (1) }\end{array}$ & $\begin{array}{l}90 / 50 \text { ratio } \\
(2)\end{array}$ & $\begin{array}{l}10^{\text {th }} \text { Percentile } \\
\text { of Income } \\
\text { (in } \$ 10,000 \mathrm{~s} \text { ) } \\
(3)\end{array}$ & $\begin{array}{c}50^{\text {th }} \text { Percentile } \\
\text { of Income } \\
\text { (in } \$ 10,000 \mathrm{~s} \text { ) } \\
(4)\end{array}$ & $\begin{array}{c}\text { Income Share } \\
\text { top } 1 \% \\
\text { (5) }\end{array}$ \\
\hline $\begin{array}{l}\text { Correlation between 50/10 ratio } \\
\text { and characteristic: }\end{array}$ & & 0.57 & -0.65 & -0.14 & 0.39 \\
\hline $\begin{array}{l}\text { 50/10 Ratio* } \\
\text { Mom HS Dropout }\end{array}$ & $\begin{array}{c}0.073 \\
(0.018)\end{array}$ & $\begin{array}{c}0.071 \\
(0.024)\end{array}$ & $\begin{array}{c}0.068 \\
(0.027)\end{array}$ & $\begin{array}{c}0.073 \\
(0.019)\end{array}$ & $\begin{array}{c}0.069 \\
(0.021)\end{array}$ \\
\hline $\begin{array}{l}\text { 50/10 Ratio* } \\
\text { Mom HS Graduate }\end{array}$ & $\begin{array}{c}0.028 \\
(0.016)\end{array}$ & $\begin{array}{c}0.018 \\
(0.018)\end{array}$ & $\begin{array}{c}0.037 \\
(0.021)\end{array}$ & $\begin{array}{c}0.029 \\
(0.015)\end{array}$ & $\begin{array}{c}0.025 \\
(0.018)\end{array}$ \\
\hline $\begin{array}{l}\text { State Characteristic* } \\
\text { Mom HS Dropout }\end{array}$ & --- & $\begin{array}{c}0.009 \\
(0.056)\end{array}$ & $\begin{array}{l}-0.002 \\
(0.005)\end{array}$ & $\begin{array}{r}-0.0002 \\
(0.001)\end{array}$ & $\begin{array}{c}0.002 \\
(0.002)\end{array}$ \\
\hline $\begin{array}{l}\text { State Characteristic* } \\
\text { Mom HS Graduate }\end{array}$ & --- & $\begin{array}{c}0.045 \\
(0.039)\end{array}$ & $\begin{array}{c}0.002 \\
(0.004)\end{array}$ & $\begin{array}{l}0.0002 \\
(0.001)\end{array}$ & $\begin{array}{c}0.002 \\
(0.002)\end{array}$ \\
\hline
\end{tabular}

Notes: Reported standard errors (in parenthesis) are adjusted for clustering at the state level. Additional explanatory variables in each regression include maternal educational attainment, gender (where appropriate) race/ethnicity, and an indicator variable for living with a single parent at age 14, along with state and cohort fixed effects. The sample includes data from the ELS, NLSY79, and NLSY97. The total sample size is 11,013 boys. 
Appendix Table 2: Impact of Measures of Segregation on Boys’ Likelihood of Dropping Out of High School, by Socioeconomic Status (MSA Level)

\begin{tabular}{lcccc} 
& $\begin{array}{c}\text { Racial } \\
\text { ratio } \\
(1)\end{array}$ & $\begin{array}{c}\text { Segregation } \\
\text { Index } \\
(2)\end{array}$ & $\begin{array}{c}\text { Income } \\
\text { Segregation } \\
\text { Index } \\
(3)\end{array}$ & $\begin{array}{c}\text { Poverty } \\
\text { Segregation } \\
\text { Index } \\
(4)\end{array}$ \\
\hline $\begin{array}{l}\text { Correlation between 50/10 } \\
\text { ratio and characteristic: }\end{array}$ & & 0.52 & 0.31 & 0.36 \\
\hline 50/10 Ratio* & 0.073 & 0.045 & 0.066 & 0.065 \\
$\quad$ Mom HS Dropout & $(0.018)$ & $(0.022)$ & $(0.018)$ & $(0.018)$ \\
50/10 Ratio* & 0.028 & 0.026 & 0.024 & 0.024 \\
$\quad$ Mom HS Graduate & $(0.016)$ & $(0.020)$ & $(0.017)$ & $(0.018)$ \\
State Characteristic* & --- & 0.267 & 0.570 & 0.640 \\
$\quad$ Mom HS Dropout & -- & $(0.116)$ & $(0.372)$ & $(0.460)$ \\
State Characteristic* & --- & 0.027 & 0.352 & 0.341 \\
$\quad$ Mom HS Graduate & -- & $(0.084)$ & $(0.302)$ & $(0.349)$ \\
\hline \hline
\end{tabular}

Notes: see notes to Appendix Table 1. Interacted state characteristic is listed in column headers. 
Appendix Table 3: Impact of Potential Mediating/Confounding Factors on Boys' Likelihood of Dropping Out of High School, by Socioeconomic Status

\begin{tabular}{lccc} 
& $\begin{array}{c}\text { 50/10 ratio } \\
(1)\end{array}$ & $\begin{array}{c}\text { Fraction } \\
\text { Single Parent } \\
(5)\end{array}$ & $\begin{array}{c}\text { Fraction Employed in } \\
\text { Manufacturing } \\
(5)\end{array}$ \\
\hline $\begin{array}{l}\text { Correlation between 50/10 ratio and } \\
\text { characteristic: }\end{array}$ & & 0.56 & -0.09 \\
\hline 50/10 Ratio* & 0.073 & 0.059 & 0.074 \\
$\quad$ Mom HS Dropout & $(0.018)$ & $(0.027)$ & $(0.018)$ \\
50/10 Ratio* & 0.028 & 0.008 & 0.029 \\
$\quad$ Mom HS Graduate & $(0.016)$ & $(0.018)$ & $(0.015)$ \\
State Characteristic* & --- & 0.418 & -0.115 \\
$\quad$ Mom HS Dropout & -- & $(0.409)$ & $(0.177)$ \\
State Characteristic* & --- & 0.550 & -0.112 \\
$\quad$ Mom HS Graduate & --- & $(0.268)$ & $(0.127)$ \\
\hline \hline
\end{tabular}

Notes: see notes to Appendix Table 1. Interacted state characteristic is listed in column headers. 


\section{DATA APPENDIX: MEASURING EDUCATIONAL ATTAINMENT IN NLSY AND NCES DATA}

This data appendix provides further details regarding the specific samples used in our analysis. All calculations performed include the sample restrictions described in the text, where we indicate that respondents whose educational attainment by age 20 is unknown and those whose mother's educational attainment is unknown are not included in the sample.

\section{NATIONAL LONGITUDINAL SURVEYS OF YOUTH}

\section{A. 1979 Cohort}

This data source originally surveyed 12,686 respondents born between 1957 and 1964, who were between the ages of 14 and 22 on the first survey date in 1979. The sample is not nationally representative, but sample weights are available to provide national representative estimates. Retention rates have been very high in these data, reducing the likelihood of attrition bias, particularly over relatively short periods. Respondents were re-interviewed every year through 1994 and then every other year after that. Because the NLSY is not a school-based survey, the universe of respondents is not restricted to those currently enrolled in a certain grade, as in the NCES data sources described below. On the other hand, some respondents are older than mandatory schooling ages on the initial survey and report their ultimate educational attainment and the timing of its completion retrospectively, introducing the possibility of recall bias.

\section{B. 1997 Cohort}

These data include information on 8,984 respondents who were born between 1980 and 1984, making them 12 to 18 on the first survey date. The sample is not nationally representative, but weights are available to provide nationally representative estimates. 
Retention rates have been very high in these data, reducing the likelihood of attrition bias, particularly over relatively short periods. Respondents have been re-interviewed every other year since 1997 with the most recent available survey having been completed in 2011. Relative to the NLSY79, these data have the advantage that virtually all students are still in school at the time of the initial survey, so we can more reliably track their high school degree status as they age.

\section{NATIONAL CENTER FOR EDUCATIONAL STATISTICS DATA}

\section{A. High School and Beyond (HSB)}

HSB initially surveyed high school sophomores and seniors in the spring of 1980; we restrict our attention to the sophomores, most of whom were around 16 years old in that year. Respondents were re-interviewed every two years through 1986 and then again in 1992. HSB is a school-based survey; specific schools were selected to participate and the survey was administered to several students within the school. Over 30,000 sophomores in 1,015 high schools were surveyed in 1980. Of the original sample, half were selected to participate in the follow-up surveys and 79 percent responded to the follow-up survey. We restricted our analysis to those students who also participated in the base year survey.

We measure respondents' educational attainment in the second follow up, conducted in the spring and summer of 1984, when the respondents would have been around 20 years old. The second follow-up survey asks a direct question about whether respondents had graduated from high school. Respondents could have reported in response that they had graduated, had left school, were still enrolled in school, or whether they had earned a GED. For those still enrolled in school in the second follow-up, we code them as not having completed their degree by age 20 (i.e. as a “drop out”). 


\section{B. National Education Longitudinal Survey (NELS)}

NELS initially surveyed $8^{\text {th }}$ graders in the spring of 1988 , when most of them were 14 years old. They were re-interviewed in 1990, 1992, 1994, and 2000. In total, 14,915 respondents were interviewed initially in 1988 and again in the 1994 round, which represents the point at which we measure educational outcomes. Survey responses regarding educational attainment were recorded in each of these survey years and a subsample of these responses were checked against transcript records indicating their accuracy. The survey excluded 5.4 percent of selected students in the base year "because of physical or mental disabilities, or because of limited English language proficiency” (Ingels and Quinn, 1996). This restriction introduces sample selection bias since these students are more likely to drop out of high school subsequently.

The sample was "freshened" in subsequent surveys so that representative estimates could be drawn for the sophomore class in 1990 and the senior class in 1992. We focus on those respondents surveyed in the base year because using respondents from the refreshed sample would introduce an upward bias in measures of educational attainment in these data. Those students who have made it to their sophomore or senior years are a positively selected group of students, as we discuss below.

\section{Education Longitudinal Survey of 2002 (ELS)}

This survey included students who were in $10^{\text {th }}$ grade in the spring of 2002. Students were re-surveyed in 2004 and 2006, so that they are around 20 years old in the latest year of available data. There were 15,300 students who responded to both the base year survey and the 2006 survey, when educational outcomes were measured.

\section{DESCRIPTIVE STATISTICS}


As Heckman and LaFontaine (2010) make clear, comparing educational attainment statistics from various micro datasets is a difficult task because of the idiosyncrasies of each. It is not our goal to track trends using these datasets, as they did, so we do not try to reconcile these differences. We do report statistics on educational attainment from each of them, though, for the purposes of detailing those differences and comparing the calculated statistics with outside sources for verification. In our econometric analysis, we control for these differences by including "dataset fixed effects.”

Appendix Table 1 indicates the percentage of survey respondents who graduate from high school, receive a GED, or drop out of high school in each dataset. Sample weights are used to adjust for the various sampling techniques used in each dataset. Discrepancies across datasets are extensive, yet they are consistent with past estimates (allowing for modest variation attributable to the sample restrictions we impose). For instance, Hill and Holzer (2007) examine data from the two NLSY surveys. We focus on educational attainment by age 20 and they focus on educational outcomes between 20 and 22. We find that 16.3 and 12.2 percent dropped out of high school and 5.1 percent and 6.9 percent have a GED in the 1979 and 1997 surveys, respectively. Their results are comparable: 16.8 percent and 12.8 percent dropped out and 4.3 percent and 5 percent earned a GED in the respective surveys. For HSB, we are able to replicate reported results (National Center for Educational Statistics, 1984), although our sample restrictions change the final values reported in this table somewhat. We match previous estimates because we are coding high school completion status directly for a single survey question. In the NELS, we estimate that 9.3 percent of students drop out and 5.0 percent of students obtain a GED by around age 20. Our estimates are comparable to those in Hurst, et al. (2004), who find that 12 percent of students drop out and 6 percent of students obtained a GED 
by 1994 (when most respondents are age 20). In the ELS, we estimate that 7.5 percent of students drop out of high school and 4.3 percent obtain a GED by around age 20. This compares to 7.8 percent and 3.9 percent, respectively, reported in Bozick, et al. (2007).

It is difficult to determine the extent to which the differences in estimates across datasets are attributable to changes in outcomes over time or the differences in the nature of the surveys. An important difference is the sampling strategies used by the different surveys. The three NCES surveys are school-based and require students to be still enrolled in school to participate. This is particularly troublesome with the HSB and ELS surveys, in which youth need to "survive" to $10^{\text {th }}$ grade to participate. In the NELS, students only need to "survive" to $8^{\text {th }}$ grade, which is less likely to introduce bias. Nevertheless, these sampling strategies indicate that we should expect higher dropout rates in the two NLSY survives, which is exactly what we see. It would also be reasonable that NELS had the next highest dropout rate and that hypothesis is confirmed in these data as well.

To better document this problem, we use data from the two NLSY surveys to examine the degree status of students and their highest grade completed at age 20. The results are presented in Appendix Table 2. In the NLSY79 and NSLY97, 5.1 percent and 6.9 percent of respondents, respectively, never make it to $10^{\text {th }}$ grade by age 20 . Of those who fail to reach that grade, most drop out. Omitting those students from the sample, as occurs in the HSB and ELS, imposes an upward bias in educational attainment. Indeed, this is a problem, albeit considerably smaller, even when starting a sample in $8^{\text {th }}$ grade, as occurs in the NELS. Around half a percent of students fail to reach that grade in the two NLSY surveys. 
Data Appendix Table 1: Educational Attainment Measured in Alternative Longitudinal Data Sources.

\section{Educational Attainment by Age 20}

\begin{tabular}{lccc} 
& GED & $\begin{array}{c}\text { High School } \\
\text { Dropout }\end{array}$ & $\begin{array}{c}\text { High School } \\
\text { Graduate }\end{array}$ \\
\hline NLSY79 & 5.1 & 16.3 & 78.6 \\
HSB (1980) & 3.8 & 7.1 & 89.2 \\
NELS (1988) & 5.0 & 9.3 & 85.7 \\
NLSY97 & 6.9 & 12.2 & 81.0 \\
ELS (2002) & 4.3 & 7.5 & 88.3 \\
\hline \hline
\end{tabular}

Source: Authors' calculations.

Data Appendix Table 2: Degree Status by Highest Grade Completed at Age 20

\begin{tabular}{|c|c|c|c|c|c|c|}
\hline & $\begin{array}{c}\text { Below } 8^{\text {th }} \\
\text { Grade }\end{array}$ & $\begin{array}{c}8^{\text {th }} \\
\text { Grade }\end{array}$ & $\begin{array}{c}9^{\text {th }} \\
\text { Grade }\end{array}$ & $\begin{array}{l}10^{\text {th }} \\
\text { Grade }\end{array}$ & $\begin{array}{l}11^{\text {th }} \\
\text { Grade }\end{array}$ & $\begin{array}{l}12^{\text {th }} \text { Grade } \\
\text { and Higher }\end{array}$ \\
\hline \multicolumn{7}{|c|}{ NLSY79 } \\
\hline $\begin{array}{l}\text { Percent at Level } \\
\text { Degree Status: }\end{array}$ & 0.7 & 1.6 & 2.8 & 4.3 & 5.0 & 85.6 \\
\hline $\begin{array}{l}\text { HS Dropout } \\
\text { GED } \\
\text { HS Graduate }\end{array}$ & $\begin{array}{c}99.4 \\
0.0 \\
0.6 \\
\end{array}$ & $\begin{array}{c}97.4 \\
1.3 \\
1.3 \\
\end{array}$ & $\begin{array}{c}95.7 \\
3.1 \\
1.3 \\
\end{array}$ & $\begin{array}{c}95.5 \\
4.4 \\
0.1 \\
\end{array}$ & $\begin{array}{c}89.5 \\
4.8 \\
5.8 \\
\end{array}$ & $\begin{array}{c}3.3 \\
5.4 \\
91.4 \\
\end{array}$ \\
\hline \multicolumn{7}{|c|}{ NLSY97 } \\
\hline $\begin{array}{l}\text { Percent at Level } \\
\text { Degree Status: }\end{array}$ & 0.4 & 2.6 & 3.9 & 5.1 & 6.0 & 82.0 \\
\hline $\begin{array}{l}\text { HS Dropout } \\
\text { GED } \\
\text { HS Graduate }\end{array}$ & $\begin{array}{c}93.9 \\
4.6 \\
1.6\end{array}$ & $\begin{array}{c}73.7 \\
23.2 \\
3.1\end{array}$ & $\begin{array}{c}63.6 \\
33.5 \\
2.9\end{array}$ & $\begin{array}{c}58.1 \\
38.8 \\
3.2\end{array}$ & $\begin{array}{c}59.5 \\
33.5 \\
7.0\end{array}$ & $\begin{array}{c}1.0 \\
1.2 \\
97.8\end{array}$ \\
\hline
\end{tabular}

Source: Authors' calculations. 


\section{SOURCES:}

Bozick, Robert, Erich Lauff and John Wirt (2007). Education Longitudinal Study of 2002 (ELS:2002): A First Look at the Initial Postsecondary Experiences of the High School Sophomore Class of 2002. Washington, DC: National Center for Education Statistics.

Haskins, Ron. 2008. “Education and Economic Mobility.” In Getting Ahead or Losing Ground: Economic Mobility in America, edited by Julia B. Isaacs, Isabel V. Sawhill, and Ron Haskins. Washington, DC: The Brookings Institution and the Economic Mobility Project.

Heckman, James J. and Paul A. LaFontaine (2010). "The American High School Graduation Rate: Trends and Levels,” Review of Economics and Statistics 92 (2): 244-262.

Hill, Carolyn J. and Harry J. Holzer (2007). "Labor Market Experiences and the Transition to Adulthood," in Sheldon Danziger and Cecilia Rouse (eds.) The Price of Independence: The Economics of Early Adulthood. New York: Russell Sage Foundation.

Hurst, David, Dana Kelly, and Daniel Princiotta (2004). Educational Attainment of High School Dropouts 8 Years Later. Washington, DC: U.S. Department of Education, National Center for Educational Statistics.

Ingels, Steven J., and Peggy Quinn (1996). Sample Exclusion in NELS:88: Characteristics of Base Year Ineligible Students; Changes in Eligibility Status after Four Years [National Education Longitudinal Study of 1988 Second Follow-Up]. Washington, DC: U.S. Department of Education. National Center for Education Statistics.

National Center for Education Statistics (1984). High School and Beyond, 1980: Sophomore Cohort Second Follow-up (1984). Volume I. Washington, DC: Government Printing Office. 